\title{
Production, Isotopic Composition, and Atmospheric Fate of Biologically Produced Nitrous Oxide
}

\author{
Lisa Y. Stein ${ }^{1}$ and Yuk L. Yung ${ }^{2}$ \\ ${ }^{1}$ Department of Environmental Sciences, University of California, Riverside, \\ California 92521; email: lisa.stein@ucr.edu \\ ${ }^{2}$ Division of Geological and Planetary Sciences, California Institute of Technology, \\ Pasadena, California 91125; email: yly@gps.caltech.edu
}

Key Words microorganisms, isotopic discrimination, photolysis, greenhouse gas, global budget

Abstract The anthropogenic production of greenhouse gases and their consequent effects on global climate have garnered international attention for years. A remaining challenge facing scientists is to unambiguously quantify both sources and sinks of targeted gases. Microbiological metabolism accounts for the largest source of nitrous oxide $\left(\mathrm{N}_{2} \mathrm{O}\right)$, mostly due to global conversion of land for agriculture and massive usage of nitrogen-based fertilizers. A most powerful method for characterizing the sources of $\mathrm{N}_{2} \mathrm{O}$ lies in its multi-isotope signature. This review summarizes mechanisms that lead to biological $\mathrm{N}_{2} \mathrm{O}$ production and how discriminate placement of ${ }^{15} \mathrm{~N}$ into molecules of $\mathrm{N}_{2} \mathrm{O}$ occurs. Through direct measurements and atmospheric modeling, we can now place a constraint on the isotopic composition of biological sources of $\mathrm{N}_{2} \mathrm{O}$ and trace its fate in the atmosphere. This powerful interdisciplinary combination of biology and atmospheric chemistry is rapidly advancing the closure of the global $\mathrm{N}_{2} \mathrm{O}$ budget.

\section{INTRODUCTION}

Nitrous oxide $\left(\mathrm{N}_{2} \mathrm{O}\right)$ is a potent greenhouse gas and the major source of stratospheric reactive nitrogen species that participate in the catalytic destruction of ozone. It has an atmospheric residence time of $118 \pm 25$ years (Minschwaner et al. 1998, Olsen et al. 2001). The infrared radiative forcing of $\mathrm{N}_{2} \mathrm{O}$ is about 206 times that of $\mathrm{CO}_{2}$ on a per molecule basis at present atmospheric conditions (IPCC 2001). This is illustrated in Figure 1, which shows the blackbody radiation of an atmosphere at $273 \mathrm{~K}$ and the infrared bands of $\mathrm{N}_{2} \mathrm{O}$. The fundamental bands are $v_{2}, v_{1}$, and $v_{3}$ at 589, 1285, and $2224 \mathrm{~cm}^{-1}$, respectively; the most important for greenhouse warming of the atmosphere is the $v_{1}$ band at $7.78 \mu \mathrm{m}$ (Goody \& Yung 1989). 

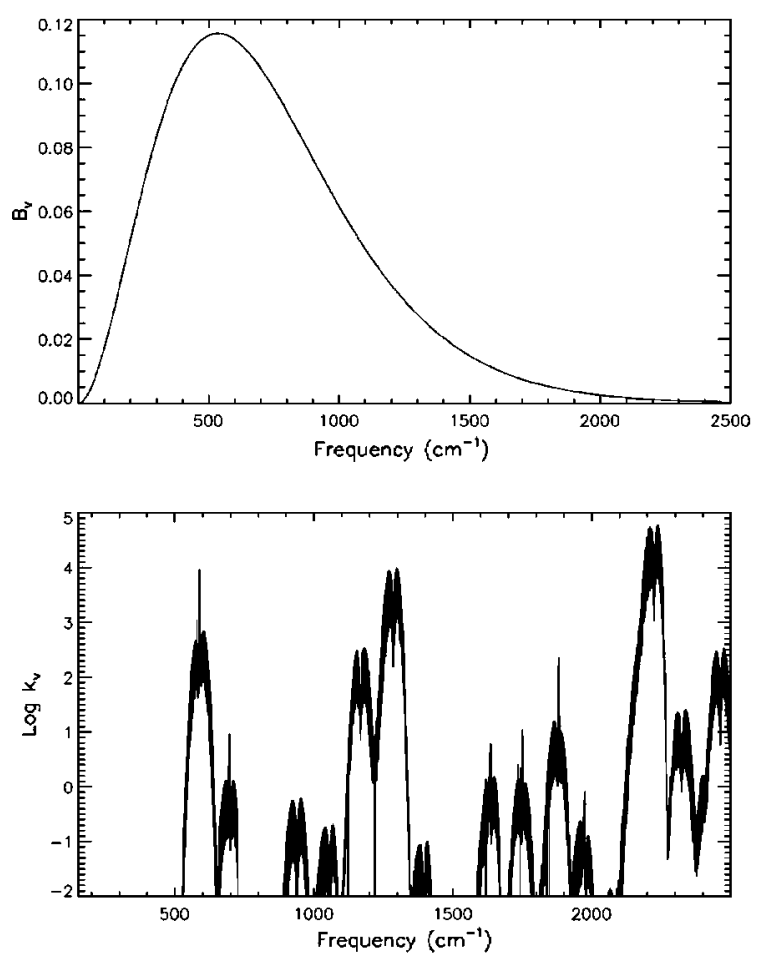

Figure 1 (a) Radiance due to a blackbody at $273 \mathrm{~K}$ as a function of wavenumber. The units are in $\mathrm{W} /\left(\mathrm{m}^{2} \mathrm{~cm}^{-1} \mathrm{sr}\right)$, where $\mathrm{sr}$ is steradian. (b) Absorption coefficient for $\mathrm{N}_{2} \mathrm{O}$ in the infrared. The strongest absorption bands are $v_{2}, v_{1}$, and $v_{3}$ at 589, 1285 and $2224 \mathrm{~cm}^{-1}$, respectively. The others are overtone or combination bands. Data taken from the HITRAN (high-resolution transmission molecular absorption database), as described in Goody \& Yung (1989).

There has been a steady increase in atmospheric $\mathrm{N}_{2} \mathrm{O}$ since the Industrial Revolution, as shown in Figure 2 (IPCC 2001). The early data are deduced from gases trapped in air bubbles in polar ice. Over the recent few decades, the concentration of $\mathrm{N}_{2} \mathrm{O}$ has been accumulating in the atmosphere (see inset of Figure 2) at a rate of $0.6 \mathrm{ppb} \cdot$ year $^{-1}$, adding to the current concentration of about $314 \mathrm{ppb}$ (parts per billion by volume) (IPCC 2001). The radiative forcing, approximately on a linear scale for small perturbations, is plotted on the right axis. There has been an increase of about $0.15 \mathrm{Wm}^{-2}$ since the Industrial Revolution. For comparison, the radiative forcing due to $\mathrm{CO}_{2}$ over the same period is about $1.4 \mathrm{Wm}^{-2}$. Although many sources of $\mathrm{N}_{2} \mathrm{O}$ have been identified, including agricultural soils, oceans, animal waste, biomass burning, fuel combustion, and industry, the combined strength of these sources calculated in 1994 only matched two thirds of the known sinks, which are removal and accumulation in the atmosphere (IPCC 2001). Upon re-evaluation of 


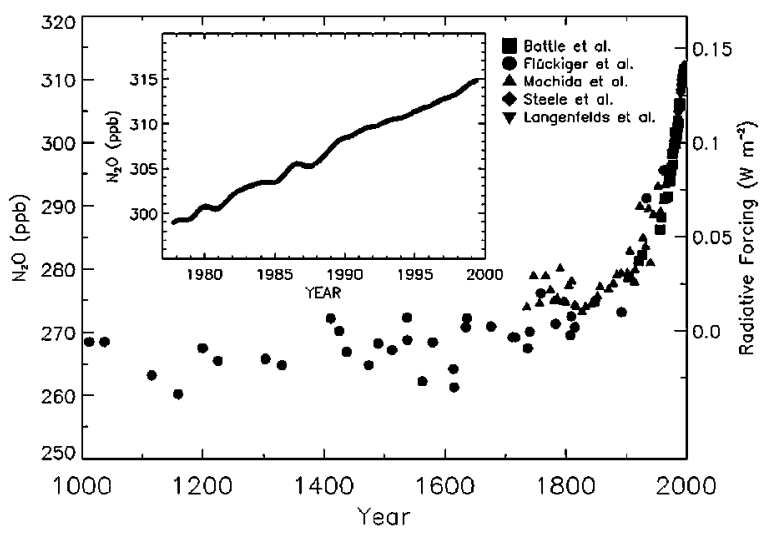

Figure $2 \mathrm{~N}_{2} \mathrm{O}$ mixing ratio for the past 1000 years as determined from ice cores, firn, and whole-air samples. Datasets are from Battle et al. (1996), Flückiger et al. (1999), Langenfields et al. (1996), Machida et al. (1995), and Steele et al. (1996). Radiative forcing, approximately on a linear scale, is plotted on the right axis. Deseasonalized global averages are plotted in the inset (Butler et al. 1998). Figure taken from IPCC (2001).

the strength of each source, it was found that the application of nitrogen-based fertilizers to agricultural soils accounted for a much larger source of $\mathrm{N}_{2} \mathrm{O}$ than previously thought (Mosier \& Kroeze 1998, Nevison \& Holland 1997). By 1998, the balance between the total sources and total sinks of $\mathrm{N}_{2} \mathrm{O}$ added up to a budget of $16 \mathrm{Tg} \mathrm{N} \cdot$ year $^{-1}$ (IPCC 2001). However, large uncertainty remains as to the actual strength of individual sources of $\mathrm{N}_{2} \mathrm{O}$ (Table 1).

Increased fertilizer usage over the past several years has stimulated the rates of microbial metabolism, especially those processes involved in the nitrogen cycle (Figure 3). Nitrification and denitrification are the primary metabolic activities leading to $\mathrm{N}_{2} \mathrm{O}$ production. However, several physiological and ecological feedbacks can greatly influence the rates of these metabolic pathways. One of the purposes of this review is to examine the diversity of enzymatic, organismal, community, and environmental factors that are simultaneously involved in producing $\mathrm{N}_{2} \mathrm{O}$. Once we achieve an understanding of the complexity of $\mathrm{N}_{2} \mathrm{O}$ production by microbial communities, the next goal is to quantify how much $\mathrm{N}_{2} \mathrm{O}$ is produced by nitrification and denitrification under a particular set of environmental conditions.

To accomplish this feat, many researchers are attempting to track discrete sources of $\mathrm{N}_{2} \mathrm{O}$ accumulating in the atmosphere by using differential isotopic signatures of ${ }^{\mathrm{k}} \mathrm{N}^{\mathrm{m}} \mathrm{N}^{\mathrm{n}} \mathrm{O}$ as produced by specific microbial communities. This concept necessarily relies on enzymatic, organismal, community, and environmental factors that influence the isotopic ratios and intramolecular site-preference of ${ }^{15} \mathrm{~N}$. Here, we review current research on organisms and enzymes within the microbial 
TABLE 1 Sources of $\mathrm{N}_{2} \mathrm{O}$ (in $\mathrm{Tg} \mathrm{N}_{\text {year }}{ }^{-1}$ )

\begin{tabular}{lclcc}
\hline Source & $\mathbf{1 9 9 4}^{\mathbf{a}}$ & Range & $\mathbf{1 9 9 0}^{\mathbf{b}}$ & Range \\
\hline Anthropogenic sources & & & & \\
$\quad$ Agricultural soils & 4.2 & $0.6-14.8$ & 3.6 & $2.8-5.7$ \\
$\quad$ Biomass burning & 0.5 & $0.2-1.0$ & 0.5 & $0.2-0.8$ \\
$\quad$ Industrial sources & 1.3 & $0.7-1.8$ & 0.7 & $0.2-1.1$ \\
$\quad$ Cattle and feedlots & 2.1 & $0.6-3.1$ & 1.0 & $0.2-2.0$ \\
$\quad$ Subtotal & 8.1 & $2.1-20.7$ & 4.1 & $1.3-7.7$ \\
Natural sources & & & & \\
$\quad$ Ocean & 3.0 & $1.0-5.0$ & 3.6 & $2.8-5.7$ \\
$\quad$ Atmosphere (NH3 oxidation) & 0.6 & $0.3-1.2$ & 0.6 & $0.3-1.2$ \\
$\quad$ Tropical soils & & & & \\
$\quad$ Wet forest & 3.0 & $2.2-3.7$ & & \\
$\quad$ Dry savannas & 1.0 & $0.5-2.0$ & & \\
$\quad$ Temperate soils & & & & \\
$\quad$ Forests & 1.0 & $0.1-2.0$ & & \\
$\quad$ Grasslands & 1.0 & $0.5-2.0$ & & \\
$\quad$ All soils & & & 6.6 & \\
$\quad$ Subtotal & 9.6 & $4.6-15.9$ & 10.8 & $6.4-16.8$ \\
$\quad$ Total sources & 17.7 & $6.7-36.6$ & 14.9 & $7.7-24.5$ \\
Imbalance (trend) & 3.9 & $3.1-4.7$ & & \\
Total sinks (stratospheric) & 12.3 & $9-16$ & & \\
Implied total sources & 16.2 & & & \\
\hline
\end{tabular}

a(Kroeze 1999, Mosier et al. 1998).

b(Olivier et al. 1998).

nitrogen cycle, how isotopic site-preference and fractionation occur, measurements of $\mathrm{N}_{2} \mathrm{O}$ isotopologue and isotopomer abundances using spectroscopic techniques, and fate of $\mathrm{N}_{2} \mathrm{O}$ isotopologues and isotopomers in the atmosphere (definitions of terms in IUPAC 1997). There are three important isotopologues of $\mathrm{N}_{2} \mathrm{O},{ }^{15} \mathrm{NNO}$, $\mathrm{N}_{2}{ }^{18} \mathrm{O}$ and $\mathrm{N}_{2}{ }^{17} \mathrm{O}$, and two isotopomers, ${ }^{15} \mathrm{NNO}$ and $\mathrm{N}^{15} \mathrm{NO}$.

The isotopologues and isotopomers of $\mathrm{N}_{2} \mathrm{O}$ will greatly advance our understanding of the budgets of these gases, primarily because atmospheric budgets of trace gas species must balance for both the species as a whole and also for individual isotopic analogs. Because most sources and sinks have characteristic fractionation processes, the different isotopic species provide valuable additional constraints in determining the budgets of these gases. The expansion of the database to include isotopic composition obviously increases the information content of the system under study, but it comes with a challenge. The basic physical, chemical, biological, and atmospheric processes must be well understood before isotopic information can be used to place useful constraints on sources and sinks of $\mathrm{N}_{2} \mathrm{O}$. 


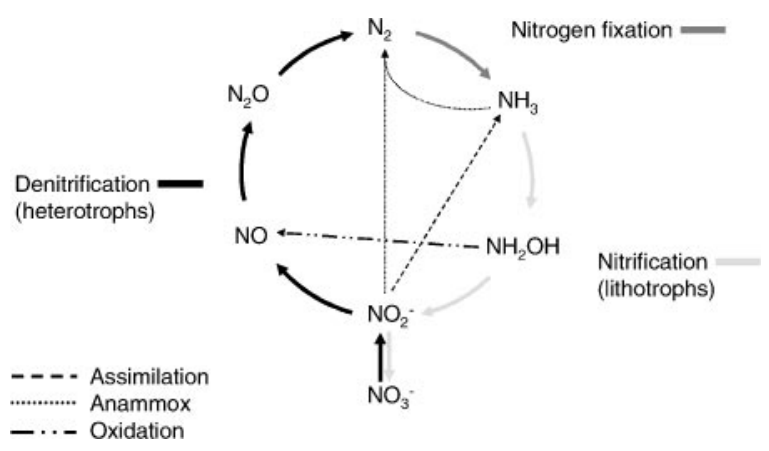

Figure 3 Microbial nitrogen cycle.

A most powerful method for characterizing the sources of $\mathrm{N}_{2} \mathrm{O}$ (and other biogenic trace gases as well) lies in its multi-isotope signature, as demonstrated in the seminal work by Kim \& Craig (1993). The measurements made in this study for $\delta^{15} \mathrm{~N}$ versus $\delta^{18} \mathrm{O}$ in $\mathrm{N}_{2} \mathrm{O}$ are summarized in Figure 1 of their paper [an updated version is reproduced here as Figure $4 ; \delta=\left(\mathrm{R} / \mathrm{R}_{\text {standard }}-1\right) \times 1000$, where $\mathrm{R}=$ isotopic ratio (Craig 1961)]. The reference isotopic fractionations of atmospheric $\mathrm{N}_{2}$ and $\mathrm{O}_{2}$ are taken to be zero. Average tropospheric $\mathrm{N}_{2} \mathrm{O}$ has $\delta^{15} \mathrm{~N}=7.0$ and $\delta^{18} \mathrm{O}=20.7$ per mil. In the stratosphere, $\delta^{15} \mathrm{~N}$ and $\delta^{18} \mathrm{O}$ appear to be enriched by as much as 15 and 12 per mil, respectively, relative to tropospheric $\mathrm{N}_{2} \mathrm{O}$. These startling results for stratospheric $\mathrm{N}_{2} \mathrm{O}$ were confirmed and extended by Rahn \& Wahlen (1997). Referring to Figure 4, the significant results of Kim \& Craig (1993) are (a) the major land biospheric sources of $\mathrm{N}_{2} \mathrm{O}$ are light in both ${ }^{15} \mathrm{~N}$ and ${ }^{18} \mathrm{O}$, relative to tropospheric $\mathrm{N}_{2} \mathrm{O}$; $(b)$ stratospheric $\mathrm{N}_{2} \mathrm{O}$ is enriched in both ${ }^{15} \mathrm{~N}$ and ${ }^{18} \mathrm{O}$, relative to tropospheric $\mathrm{N}_{2} \mathrm{O}$; and $(c)$ there is a large "back flux" of ${ }^{15} \mathrm{~N}$ enriched $\mathrm{N}_{2} \mathrm{O}$ from the stratosphere to the troposphere in order to account for the isotopic composition of tropospheric $\mathrm{N}_{2} \mathrm{O}$. A large part of the recent work on $\mathrm{N}_{2} \mathrm{O}$ consists of understanding the underlying mechanism of isotopic fractionation in the atmosphere implied by Kim \& Craig (1993) (Johnson et al. 2001, Yung \& Miller 1997).

\section{MICROBIAL PATH WAYS THAT PRODUCE $\mathrm{N}_{2} \mathrm{O}$}

\section{Microbial Nitrogen Transformations and Intramolecular Site Preference of ${ }^{15} \mathrm{~N}$}

The requirement for nitrogen in biological molecules necessitates a diversity of mechanisms for assimilating nitrogen into the living cell. The majority of assimilatory mechanisms in bacteria, except the direct fixation of $\mathrm{N}_{2}$, require the uptake of either ammonia $\left(\mathrm{NH}_{3}\right)$ or nitrate $\left(\mathrm{NO}_{3}^{-}\right)$. In addition to assimilation, nitrogenous 


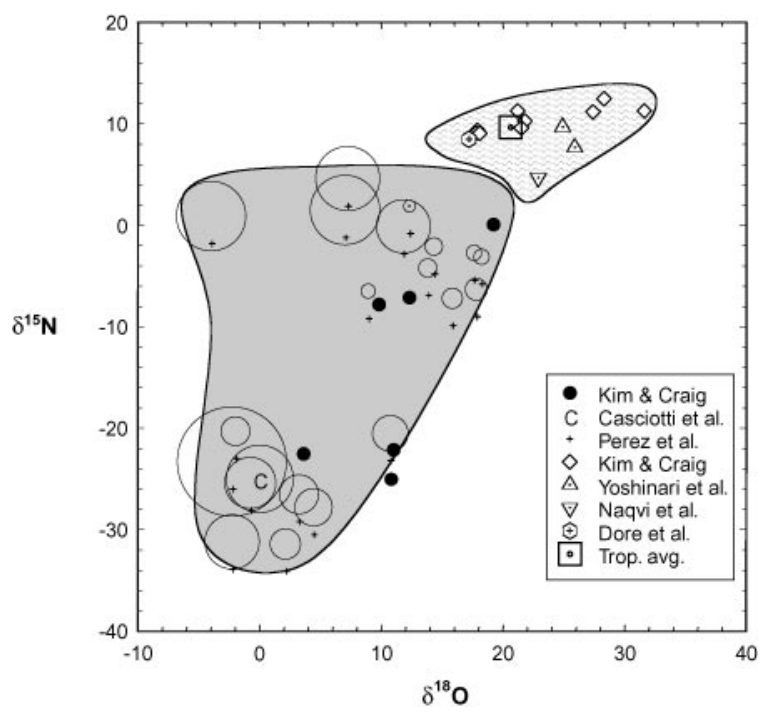

Figure 4 A plot of $\delta^{15} \mathrm{~N}$ versus $\delta^{18} \mathrm{O}$ with highlighted fields representing the range of data found in surface oceans ( gray field) and terrestrial systems (textured field). Symbols representing the work of various authors are defined in the legend. The oceanic results shown from Kim \& Craig (1990) are the measured values in the top $1000 \mathrm{~m}$ of the subtropical Pacific Ocean. The symbols representing Yoshinari et al. (1997) are the near-surface averages of their data from the Indian Ocean and Arabian Sea. Also from the Arabian Sea is the near-surface average of Naqvi et al. (1998). The subtropical North Pacific end-member value proposed by Dore et al. (1998) is also shown. In the terrestrial field, the open circles associated with the data of Pérez et al. (2000) and Casciotti et al. (1997) are proportional to the relative magnitude of the flux for each of the points. Terrestrial data of Kim \& Craig (1993) have no concurrent flux results. The open square is the commonly reported average value of tropospheric $\mathrm{N}_{2} \mathrm{O}$. The $\delta^{15} \mathrm{~N}$ and $\delta^{18} \mathrm{O}$ values are referenced to atmospheric $\mathrm{N}_{2}$ and $\mathrm{O}_{2}$, respectively. Taken from Rahn \& Wahlen (2000).

compounds are also extremely important for energy generation due to the spectrum of oxidation states from -3 to +5 (Table 2). Microbial enzymes have evolved that specialize in shuttling electrons to or from these various molecules, and several are described in Table 3.

Both assimilatory and dissimilatory processes are important for the fractionation and final placement of isotopes within $\mathrm{N}_{2} \mathrm{O}$ molecules, although dissimilatory processes have the largest effects. The enzymes in dissimilatory pathways process a large flux of molecules relative to assimilatory pathways, and isotopic discrimination is based predominantly on catalytic rate and number of enzymatic steps (Cleland et al. 1977). In general, enzymes prefer to transform molecules with a smaller molecular weight, such that the end products within a nitrogen transformation pathway will almost always be isotopically lighter than molecules 
TABLE 2 Oxidation state of nitrogenous compounds

\begin{tabular}{lll}
\hline Compound & $\begin{array}{l}\text { Chemical } \\
\text { formula }\end{array}$ & $\begin{array}{l}\text { Oxidation } \\
\text { state }\end{array}$ \\
\hline Ammonia & $\mathrm{NH}_{3}$ & -3 \\
Hydrazine & $\mathrm{N}_{2} \mathrm{H}_{4}$ & -2 \\
Diimine & $\mathrm{N}_{2} \mathrm{H}_{2}$ & -1 \\
Hydroxylamine & $\mathrm{NH}_{2} \mathrm{OH}$ & -1 \\
Dinitrogen & $\mathrm{N}_{2}$ & 0 \\
Nitrous oxide & $\mathrm{N}_{2} \mathrm{O}$ & +1 \\
Nitric oxide & $\mathrm{NO}$ & +2 \\
Nitrite & $\mathrm{NO}_{2}^{-}$ & +3 \\
Nitrogen dioxide & $\mathrm{NO}_{2}$ & +4 \\
Nitrate & $\mathrm{NO}_{3}^{-}$ & +5 \\
\hline
\end{tabular}

in prior steps. However, as is evident in Figure 3, there are pathways that contribute to the formation of $\mathrm{N}_{2} \mathrm{O}$ and those that consume it. These pathways are in constant competition depending on environmental conditions and can lead to a range of ${ }^{15} \mathrm{~N}$ values based on the number and type of enzymatic steps involved. Additionally, some enzymes will allow for the exchange of substrate molecules at the activesite of the enzyme before the conversion of substrate to product is complete. This process will lead to less isotopic discrimination of nitrogen due to the slowed rate of catalysis, as occurs in the process of nitrogen fixation (Beaumont et al. 2000, Hoering \& Ford 1960).

The complexity of enzymatic possibilities, processivity of reactions (i.e., rate of exchange), and competition between pathways makes the task of quantifying individual microbial contributions to the budget and isotopic fractionation of $\mathrm{N}_{2} \mathrm{O}$ very difficult. The following descriptions explain, in basic terms, the pathways that are found in broad groups of microorganisms, how discrete enzymatic pathways might fractionate ${ }^{15} \mathrm{~N}$ leading to a traceable isotopic signature in the $\mathrm{N}_{2} \mathrm{O}$ pool, and how environmental factors influence the activities of microbial groups leading to bias in the composition of $\mathrm{N}_{2} \mathrm{O}$ isotopologues and isotopomers.

\section{Nitrification}

The process of nitrification includes the oxidation of ammonia to nitrate via nitrite (Figure 3). Several groups of microorganisms are involved in nitrification-some use it for their central metabolism, whereas others perform parts of the process fortuitously through co-metabolism (Prosser 1986). The first four groups of bacteria listed in Table 3 all participate in nitrification to varying degrees.

The best characterized microbial pathway for the oxidation of ammonia to nitrite $\left(\mathrm{NO}_{2}^{-}\right)$is performed by chemolithotrophic bacteria, i.e., they consume only inorganic substrates to generate energy, and in the case of ammonia oxidizers, 
TABLE 3 Bacteria in the nitrogen cycle and their enzymes

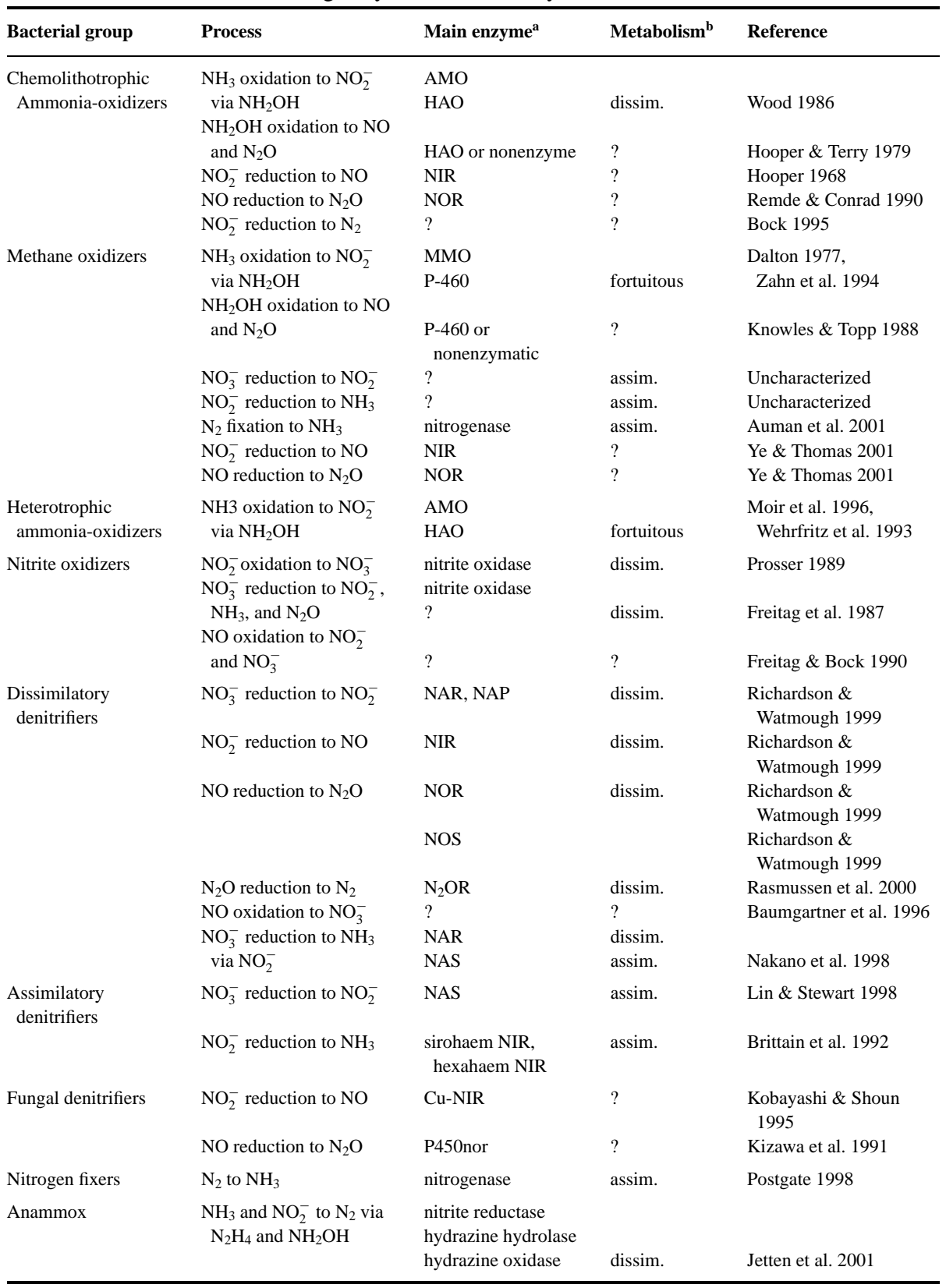

Enzyme acronyms from cited references.

Assim.$=$ assimilatory, dissim.$=$ dissimilatory, fortuitous $=$ co-metabolic . 
they fix inorganic carbon. Ammonia-oxidizing bacteria require molecular oxygen to perform their metabolism and produce hydroxylamine $\left(\mathrm{NH}_{2} \mathrm{OH}\right)$ as a metabolic intermediate (Wood 1986). Ammonia oxidation by these bacteria is highly stimulated by the addition of nitrogen-based fertilizers to agricultural soils, and the $\mathrm{NO}_{2}^{-}$they produce stimulates other processes in the nitrogen cycle, including the production of $\mathrm{N}_{2} \mathrm{O}$ (Conrad 1996). Ammonia oxidizers are also capable of producing $\mathrm{N}_{2} \mathrm{O}$ under microaerophilic conditions by directly reducing $\mathrm{NO}_{2}^{-}$, presumably through the activities of denitrifying enzymes (Goreau et al. 1980, Hooper 1968). This process, known as aerobic or lithotrophic denitrification, has been observed in only a small group of ammonia-oxidizing species (Casciotti \& Ward 2001, Colliver $\&$ Stephenson 2000). However, the enzymes involved, the phylogenetic breadth, and metabolic purpose remain unknown.

Methane-oxidizing bacteria, or methanotrophs, are closely related evolutionarily to the ammonia oxidizers (Holmes et al. 1995). These bacteria oxidize ammonia to $\mathrm{NO}_{2}^{-}$through a co-metabolic process, and thus do not gain energy from it (Dalton 1977). They also reduce $\mathrm{NO}_{2}^{-}$to $\mathrm{N}_{2} \mathrm{O}$ similarly to ammonia oxidizers, but this metabolism is even less well characterized for the methanotrophs than for the ammonia oxidizers (Knowles \& Topp 1988, Yoshinari 1984). The contribution of methanotrophs to the $\mathrm{N}_{2} \mathrm{O}$ budget is currently unknown, but may be significant (Mandernack et al. 2000). As shown in Table 3, methanotrophs also process nitrogen through other metabolic processes, including the consumption of NO, which is the substrate for $\mathrm{N}_{2} \mathrm{O}$ production (Krämer et al. 1990).

Heterotrophic ammonia-oxidizers, bacteria that consume organic carbon as their primary metabolism, also oxidize ammonia to $\mathrm{NO}_{2}^{-}$, but like the methanotrophs, they do not gain energy from it (Killham 1986, Verstraete 1975). It is thought that these bacteria could oxidize as much ammonia as the chemolithotrophic ammonia-oxidizers provided that enough organic carbon is available for energy production (Kuenen \& Robertson 1994). Additionally, many heterotrophic nitrifiers reduce $\mathrm{NO}_{2}^{-}$to $\mathrm{N}_{2} \mathrm{O}$ under microaerophilic conditions using standard denitrifying enzymes (Table 3) (Castignetti et al. 1984). Therefore, the chemolithotrophic ammonia-oxidizers, methanotrophs, and heterotrophic ammonia-oxidizers all occupy the same environmental niche and are all extremely important for $\mathrm{N}_{2} \mathrm{O}$ production in aerobic zones (Lipschultz et al. 1981). In addition to the reduction of $\mathrm{NO}_{2}^{-}$to $\mathrm{NO}$ and $\mathrm{N}_{2} \mathrm{O}$, the oxidation of $\mathrm{NH}_{2} \mathrm{OH}$, a metabolic intermediate of ammonia oxidation, also produces $\mathrm{N}_{2} \mathrm{O}$ (Hooper \& Terry 1979). However, because $\mathrm{NH}_{2} \mathrm{OH}$ is rapidly converted to $\mathrm{NO}_{2}^{-}$in the environment, the amount of $\mathrm{N}_{2} \mathrm{O}$ from $\mathrm{NH}_{2} \mathrm{OH}$ oxidation is presumably insignificant compared to the amount produced through reduction of $\mathrm{NO}_{2}^{-}$and $\mathrm{NO}$ by denitrifying enzymes (Whittaker et al. 2000).

The other half of nitrification, $\mathrm{NO}_{2}^{-}$oxidation to $\mathrm{NO}_{3}^{-}$, is performed by a separate group of bacteria known as nitrite oxidizers (Bock \& Koops 1991). The $\mathrm{NO}_{3}^{-}$ produced by this group of bacteria provides much of the substrate for denitrification, a process discussed in the next section, which largely controls the rate of $\mathrm{N}_{2} \mathrm{O}$ production in anaerobic environments. The nitrite oxidizers have been highly understudied, but they appear to play an additional role in the direct production 
of $\mathrm{N}_{2} \mathrm{O}$ (Freitag et al. 1987), and/or in the consumption of NO (Freitag \& Bock 1990).

\section{Denitrification}

The process of denitrification, the reduction of $\mathrm{NO}_{3}^{-}$to $\mathrm{N}_{2}$ via $\mathrm{NO}_{2}^{-}, \mathrm{NO}$, and $\mathrm{N}_{2} \mathrm{O}$, is performed by a very diverse group of microorganisms, including archaea and some fungi (Kizawa et al. 1991, Zumft 1992). The enzymatic diversity and ubiquity of this pathway among microbes argue for its central role in energy generation, nitrogen assimilation, and competition in most ecosystems. Denitrifying bacteria can utilize a number of food sources from organic carbon to Fe(II) (Straub et al. 1996) and use the nitrogenous molecules as electron acceptors to complete the task of energy generation. Because denitrification is made up of a sequence of reductive events, this process is thought to occur predominantly in anaerobic environments. The potential for $\mathrm{N}_{2} \mathrm{O}$ emission from denitrification increases in water-saturated environments that contain large concentrations of organic carbon and $\mathrm{NO}_{3}^{-}$(Baumgärtner \& Conrad 1992). High concentrations of $\mathrm{NO}_{3}^{-}$inhibit the reduction of $\mathrm{N}_{2} \mathrm{O}$ to $\mathrm{N}_{2}$ and stimulate the reduction of $\mathrm{NO}$ to $\mathrm{N}_{2} \mathrm{O}$ causing the escape of $\mathrm{N}_{2} \mathrm{O}$ from soils to the atmosphere (Gaskell et al. 1981).

There has been a long-standing debate as to whether nitrifying or denitrifying processes contribute the most $\mathrm{N}_{2} \mathrm{O}$ from agricultural environments. It appears that the extent of isotopic fractionation from these processes is quite different due to energy conservation and the consumption of $\mathrm{N}_{2} \mathrm{O}$ during denitrification (Pérez et al. 2001). As discussed below, this argument will necessitate a closer look at the carbon to nitrogen ratio of soils, available oxygen, temperature, water, and $\mathrm{pH}$.

\section{Other Processes in the Nitrogen Cycle that Influence $\mathrm{N}_{2} \mathrm{O}$ Production}

Obviously, the direct production of $\mathrm{N}_{2} \mathrm{O}$ by microorganisms will have the greatest influence on isotopic fractionation. However, because all aspects of the nitrogen cycle influence the availability of substrates for $\mathrm{N}_{2} \mathrm{O}$ production or consumption, indirect processes must also be considered when quantifying the roles of individual microbial groups that participate in $\mathrm{N}_{2} \mathrm{O}$ production. In environments that are not heavily influenced by agriculture or industry, $\mathrm{N}_{2}$ fixation provides much of the ammonia that is subsequently oxidized by the three main groups of ammonia oxidizers discussed above. $\mathrm{N}_{2}$ fixation provides a ready nitrogen source for assimilation by many types of organisms in natural systems, especially plants, fungi, and bacteria (Postgate 1998). The influence of naturally occurring $\mathrm{N}_{2}$ fixation on the nitrogen cycle has recently been eclipsed by the wide-spread production and application of ammonia-based fertilizers and atmospheric deposition of ammonia from automobile exhaust and industrial processes (Howarth et al. 1996).

Bacteria that are capable of anaerobically oxidizing ammonia, a process known as anammox, also participate in the nitrogen cycle by transforming $\mathrm{NH}_{3}$ and $\mathrm{NO}_{2}^{-}$ to $\mathrm{N}_{2}$ via hydrazine and hydroxylamine intermediates (Jetten et al. 2001). It is 
currently unknown whether this process is globally relevant, but significant rates have been described in marine sediments from continental shelves (Thamdrup \& Dalsgaard 2002). Thus, under the right conditions, anammox could compete with denitrification in anaerobic environments by removing substrates that are necessary for producing $\mathrm{N}_{2} \mathrm{O}$.

\section{ENZYME STRUCTURE AS A CAUSE FOR SITE PREFERENCE OF ${ }^{15} \mathrm{~N}$ IN $\mathrm{N}_{2} \mathrm{O}$}

\section{Differences Between Nitrification and Denitrification}

As described above, there are many groups of microorganisms that perform a variety of processes leading to either production or consumption of $\mathrm{N}_{2} \mathrm{O}$ in the environment. Our eventual goal is to close the global budget for $\mathrm{N}_{2} \mathrm{O}$ by understanding the relative strength of nitrifying versus denitrifying processes. One possibility for quantifying the relative contribution of microbial groups is to find differences in the composition of $\mathrm{N}_{2} \mathrm{O}$ isotopomers and isotopologues that they each produce. In other words, is the placement of ${ }^{15} \mathrm{~N}$ and extent of ${ }^{15} \mathrm{~N}$ fractionation in $\mathrm{N}_{2} \mathrm{O}$ molecules different for each microbial process? Several studies have shown that $\mathrm{N}_{2} \mathrm{O}$ produced by nitrification is much more depleted in ${ }^{15} \mathrm{~N}$ than that produced by denitrification $(-45 \%$ o to $-66 \%$ ofor nitrification versus $-13 \%$ o to $-28 \%$ for denitrification) (Barford et al. 1999, Pérez et al. 2001, Webster \& Hopkins 1996, Yoshida 1988). This observation makes sense due to the conservation of energy during denitrification and the consumption of $\mathrm{N}_{2} \mathrm{O}$, processes that decrease the extent of isotopic fractionation.

A study by Yoshida \& Toyoda suggested that we could discriminate among $\mathrm{N}_{2} \mathrm{O}$ molecules produced by nitrification, denitrification, and bulk industrial emissions (automobile and factory) by looking at the intramolecular site-preference for ${ }^{15} \mathrm{~N}$ within the $\mathrm{N}_{2} \mathrm{O}$ molecule (Yoshida \& Toyoda 2000). This study proposed that in the $\mathrm{N}^{\beta} \mathrm{N}^{\alpha} \mathrm{O}$ molecule, $\mathrm{N}_{2} \mathrm{O}$ produced by microbes will be more fractionated at the $\mathrm{N}^{\alpha}$ than at the $\mathrm{N}^{\beta}$ position based on the formation and cleaving of the $\mathrm{N}^{\alpha}-\mathrm{O}$ bond during ammonia oxidation and $\mathrm{N}_{2} \mathrm{O}$ reduction, respectively. Following this logic, environments dominated by nitrification should result in a relatively low ratio of ${ }^{14} \mathrm{~N}^{15} \mathrm{NO}:{ }^{15} \mathrm{~N}^{14} \mathrm{NO}$, whereas denitrification-dominated environments would have a more equalized ratio due to the preferential reduction of ${ }^{15} \mathrm{~N}^{14} \mathrm{NO}$. Although hypothetically sound, the exact opposite effect has been measured for $\mathrm{N}_{2} \mathrm{O}$ emitted from fertilized agricultural soils dominated by nitrification, which showed enrichment of ${ }^{15} \mathrm{~N}$ at the central $\mathrm{N}$ position (Pérez et al. 2001). This observation is supported by the mechanism of the $\mathrm{N}_{2} \mathrm{O}$-producing enzyme as discussed below. Industrial processes were found to cause insignificant fractionation of ${ }^{15} \mathrm{~N}$ because they are not catalyzed enzymatically, and can thus be easily distinguished from biological $\mathrm{N}_{2} \mathrm{O}$ production (Yoshida \& Toyoda 2000).

Few studies have investigated the potential for site discrimination of ${ }^{15} \mathrm{~N}$ within $\mathrm{N}_{2} \mathrm{O}$ by distinct species of nitrifying versus denitrifying bacteria (Barford et al. 
1999; Garber \& Hollocher 1982a,b; Webster \& Hopkins 1996; Weeg-Aerssens et al. 1988; Yoshida 1988). Furthermore, these studies used model organisms that are not necessarily reflective of the types of bacteria that are most active in the environment (Kowalchuk et al. 1997). In addition to direct studies of model organisms, another way to approach this question is by analyzing differences in enzyme structure among different bacterial groups to predict how ${ }^{15} \mathrm{~N}$ site-preference might occur. Both nitrifiers and denitrifiers directly produce $\mathrm{N}_{2} \mathrm{O}$ through the presumed activity of at least two enzymes: nitrite reductase, which reduces $\mathrm{NO}_{2}^{-}$to $\mathrm{NO}$, and nitric oxide reductase, which reduces $\mathrm{NO}$ to $\mathrm{N}_{2} \mathrm{O}$ (Richardson \& Watmough 1999). We will limit our discussion to these two groups of enzymes because they are directly related to $\mathrm{N}_{2} \mathrm{O}$ production.

\section{Nitrite Reductase}

Nitrite reductase enzymes are fairly widespread throughout the bacterial kingdom due to the high usage of denitrification as an energy-generating process and for nitrogen assimilation (Brittain et al. 1992). There are two known types of dissimilatory nitrite reductases that reduce $\mathrm{NO}_{2}^{-}$to $\mathrm{NO}$, and one known assimilatory enzyme that reduces $\mathrm{NO}_{2}^{-}$to $\mathrm{NH}_{3}$ (Richardson \& Watmough 1999). Of the dissimilatory enzymes, the $\mathrm{cd}_{1}$-cytochrome nitrite reductase is more highly represented in the denitrifying bacteria, whereas the copper nitrite reductase is present in more taxonomically diverse species (Coyne et al. 1989, Hochstein \& Tomlinson 1988). Both types of nitrite reductase have been found in the genome of the methanotroph Methylomonas sp. strain 16a, the only dual occurrence known, but only the copper enzyme has been found in the chemolithotrophic ammonia-oxidizers (Casciotti \& Ward 2001, Ye \& Thomas 2001). Based on physiological studies, it remains inconclusive as to whether the nitrite reductase in ammonia oxidizers is actually responsible for dissimilatory nitrite reduction; however, studies are currently underway to resolve this issue (Beaumont et al. 2002).

Figure 5 compares the catalytic mechanism of $\mathrm{NO}_{2}^{-}$reduction by the $\mathrm{cd}_{1-}$ cytochrome enzyme (Figure $5 a$ ) and the copper enzyme (Figure 5b) (Cutruzzolà 1999). Although these mechanisms are largely similar, the intermediate steps may be different enough in their relative rate of catalysis to cause differences in isotopic fractionation. NO is a highly toxic product, it inhibits nitrite reductase, and it is shuttled almost instantaneously to nitric oxide reductase upon formation (Averill 1996). In fact, there was a long-standing debate as to whether NO was an independent product from nitrite reductase because it is transformed to $\mathrm{N}_{2} \mathrm{O}$ so rapidly under physiological conditions (Zumft 1993). Thus, the rate of NO formation by nitrite reductase and the rate of NO transfer to nitric oxide reductase will largely govern the fractionation of isotopes within $\mathrm{N}_{2} \mathrm{O}$ molecules.

\section{Nitric 0 xide Reductase}

Nitric oxide reductase (NOR) is likely the pivotal enzyme that determines the relative fractionation and site preference of ${ }^{15} \mathrm{~N}$ within the $\mathrm{N}_{2} \mathrm{O}$ molecule. It is 
a

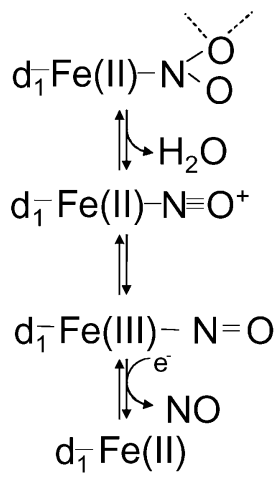

b

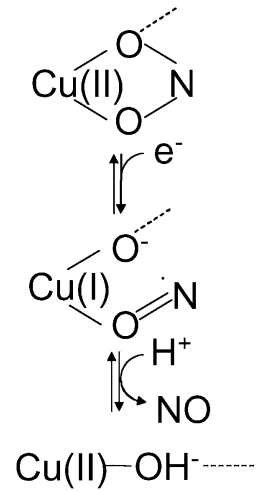

Figure 5 Catalytic mechanism of nitrite reductase - cytochrome $\mathrm{cd}_{1}(a)$ versus copper (b) active-site. Redrawn from Cutruzzolà (1999).

also the least well-characterized enzyme within the microbial nitrogen cycle. This enzyme is responsible for bringing two NO molecules together and forming the $\mathrm{N}=\mathrm{N}$ bond (Hendriks et al. 2000). There are three known classes of NOR enzymes: $\mathrm{P}-450$ nor, cNOR, and qNOR. P-450nor is found in denitrifying fungi, cNOR is the most common enzyme found in denitrifying bacteria, and qNOR is most often found in nondenitrifying pathogenic bacteria (Hendriks et al. 2000). Studies of P450nor, the best-characterized enzyme in this family, have indicated that each NO molecule binds separately to the enzyme before the formation of the $\mathrm{N}=\mathrm{N}$ bond (Shiro et al. 1995). Sequential binding could hypothetically lead to a preference for initial ${ }^{14} \mathrm{NO}$ binding followed by a slower, less-discriminatory binding of the second NO molecule (Figure $6 b$ ). Once the second NO binds, this leads to the loss of the $\mathrm{O}$ atom from the first $\mathrm{NO}$ molecule and release of $\mathrm{N}_{2} \mathrm{O}$ (Shiro et al. 1995). This model would lead to greater fractionation at the $\mathrm{N}^{\beta}$ position than the $\mathrm{N}^{\alpha}$ position (in $\mathrm{N}^{\beta} \mathrm{N}^{\alpha} \mathrm{O}$ ), contradicting the assumption proffered by Yoshida $\&$ Toyoda and leading to a higher emission of ${ }^{14} \mathrm{~N}^{15} \mathrm{NO}$ than ${ }^{15} \mathrm{~N}^{14} \mathrm{NO}$ from the microbial environment.

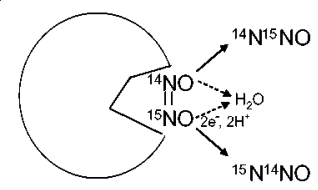

b

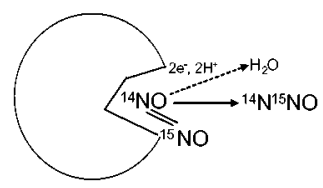

Figure 6 Simultaneous $(a)$ versus sequential $(b)$ binding of NO to NOR. Formation of predominant $\mathrm{N}_{2} \mathrm{O}$ isotopologue(s) indicated for each mechanism: Simultaneous binding leads to equivalent fractionation at $\mathrm{N}^{\alpha}$ and $\mathrm{N}^{\beta}$; sequential binding leads to greater fractionation at $\mathrm{N}^{\beta}$. 
The catalytic mechanism of cNOR remains unclear. There are two possible mechanisms for $\mathrm{NO}$ binding and reduction to $\mathrm{N}_{2} \mathrm{O}$; one requires sequential binding of the two NO molecules similarly to that of the P-450nor (Zhao et al. 1995), whereas the other suggests a simultaneous binding of the two NO molecules (Figure 6) (Averill 1996). As illustrated in Figure 6, sequential binding would result in accumulation of ${ }^{14} \mathrm{~N}$ at the $\mathrm{N}^{\beta}$ position, assuming a slower rate of binding by the second NO molecule (and thus with less bias toward the lighter molecule) and loss of the $\mathrm{O}$ atom by the first NO molecule to bind. Simultaneous binding would likely result in limited site-preference due to equal positioning of the molecules for loss of the $\mathrm{O}$ atom and release of $\mathrm{N}_{2} \mathrm{O}$ from the enzyme. Currently, there is scant evidence for sequential binding of $\mathrm{NO}$ molecules, but the finding of intramolecular site-preference for ${ }^{15} \mathrm{~N}$ in $\mathrm{N}_{2} \mathrm{O}$ emitted from fertilized soils suggests that this mechanism does occur (Pérez et al. 2001).

The qNOR enzyme, normally associated with detoxification of NO by pathogenic bacteria, has recently been identified in the genome of Methylomonas sp. strain 16a (Ye \& Thomas 2001). It is unknown whether qNOR or cNOR is the dominant enzyme in other methanotrophs or chemolithotrophic ammonia-oxidizers, as very little information is available. However, the dominance of qNOR in these bacteria would indicate that their denitrification pathway is present for detoxification rather than for energy generation. Detoxification would likely lead to a greater extent of isotopic fractionation because energy would not have to be conserved at each step in the enzymatic pathway, as is the case for denitrification. Differences in the catalytic mechanism of cNOR and qNOR are unknown, but the different physiological role of these two enzymes in denitrifiers versus nitrifiers may be pivotal in generating isotopic site-preferences.

Obviously, much more work is required to understand how the structure and function of different NOR enzymes within nitrifiers versus denitrifiers may influence the fractionation and site preference of ${ }^{15} \mathrm{~N}$ within $\mathrm{N}_{2} \mathrm{O}$ molecules. However, if the general enzymatic mechanisms are equivalent among organisms, there would be little difference in enrichment of ${ }^{15} \mathrm{~N}$ at either the central or terminal $\mathrm{N}$ positions. In this case, only the kinetics and consumption of $\mathrm{N}_{2} \mathrm{O}$ as influenced by environmental conditions would discriminate between the pathways.

\section{INFLUENCE OF THE ENVIRONMENT ON NITROGEN TRANSFORMING PATHWAYS}

The status of the environment plays an extremely important role along with organism and enzymatic diversity in both the production and amount of isotopic fractionation of $\mathrm{N}_{2} \mathrm{O}$. Among the dominating environmental factors that influence nitrification and denitrification are oxygen availability, which is determined largely by soil moisture; organic carbon versus nitrogen availability; temperature; and $\mathrm{pH}$.

So far, we have divided $\mathrm{N}_{2} \mathrm{O}$ production by oxygen availability-nitrification dominates the process in aerobic environments and denitrification dominates in 
anaerobic environments. However, there appears to be a continuum in the classes of organisms that lead to $\mathrm{N}_{2} \mathrm{O}$ production in particular regions. For example, heterotrophic ammonia-oxidizers express denitrifying enzymes with high activity under aerobic conditions (Anderson et al. 1993, Bell \& Ferguson 1991). Denitrification activity in chemolithotrophic ammonia-oxidizers is highest at reduced $\mathrm{O}_{2}$ tensions (Goreau et al. 1980). The expression of denitrifying enzymes in denitrifying bacteria is only detectable in anaerobically grown cells (Coyne et al. 1990). Based on $\mathrm{O}_{2}$ availability alone, we now have a situation where different organisms actively denitrify in different regions and, perhaps, at different times. For example, in dryer soils, chemolithotrophic ammonia-oxidizers appear to produce more NO than $\mathrm{N}_{2} \mathrm{O}$, whereas in wet soils, the bulk of $\mathrm{N}_{2} \mathrm{O}$ is produced by denitrifiers (Davidson 1993). This situation has been tested by measuring changes in the isotopic composition of emitted $\mathrm{N}_{2} \mathrm{O}$ from dry versus wet soils, an indication that the $\mathrm{N}_{2} \mathrm{O}$ isotopologue pool changes depending on the strength of nitrifying or denitrifying activities (Pérez et al. 2001).

In addition to $\mathrm{O}_{2}$ availability, the activities of microbes are also controlled by the availability of nutrients for energy generation. In nitrifying communities, the metabolic activity and population of chemolithotrophic versus heterotrophic ammonia-oxidizers are highly controlled by the carbon to nitrogen ratio $(\mathrm{C} / \mathrm{N})$. Chemolithotrophic metabolism dominates in low $\mathrm{C} / \mathrm{N}$ environments, whereas high $\mathrm{C} / \mathrm{N}$ stimulates heterotrophic ammonia oxidation (Kuenen \& Robertson 1994). Thus, $\mathrm{N}_{2} \mathrm{O}$ production in the aerobic to suboxic environment may be controlled by carbon and nitrogen as well as by oxygen availability due to the growth of one population over another. In denitrifying environments, organic carbon and nitrate availability determine whether denitrifiers produce mostly $\mathrm{N}_{2}$ or $\mathrm{N}_{2} \mathrm{O}$. To further complicate matters, some intermediates in the nitrogen cycle, such as $\mathrm{NO}_{2}^{-}$and $\mathrm{NO}$, are highly inhibitory to nitrogen-transforming enzymes, which will influence the population composition and metabolic activity of the community (Averill 1996, Stein \& Arp 1998). Thus, a buildup of $\mathrm{NO}_{2}^{-}$from ammonia oxidation, which occurs in newly fertilized agricultural fields, may stimulate $\mathrm{N}_{2} \mathrm{O}$ production by nitrifiers while inhibiting $\mathrm{N}_{2} \mathrm{O}$ production by denitrifiers.

Temperature plays an important but poorly understood role in regulating the flux of $\mathrm{N}_{2} \mathrm{O}$ from the environment. In soils, increasing temperatures generally increase the rates of biological activity (Radmer \& Kok 1979). This is potentially an extremely important effect because as the mean temperature of Earth increases due to global warming, more greenhouse gases will be released, possibly causing a run-away greenhouse effect (Crutzen 1983). Few studies have shown whether rates of denitrification change in different climatic regions or with imposed changes in temperature, and contradictory results have been described (Powlson et al. 1988, Saad \& Conrad 1993). More work is necessary to determine whether temperature is a strong factor in predicting $\mathrm{N}_{2} \mathrm{O}$ emissions from the environment.

The $\mathrm{pH}$ of the environment may also have an effect on the production of $\mathrm{N}_{2} \mathrm{O}$ because $\mathrm{NO}_{2}^{-}$chemically decomposes to $\mathrm{NO}_{2}$ and $\mathrm{NO}$ under acidic conditions (Reuss \& Smith 1965). The activity of chemolithotrophic ammonia-oxidizers 
produces large amounts of acidity, which will influence the $\mathrm{pH}$ of their immediate surroundings (Wood 1986). Studies on the effects of $\mathrm{pH}$ on the release of $\mathrm{N}_{2} \mathrm{O}$ from soils have indicated that multiple complex interactions that are difficult to interpret occur between organisms and enzyme populations (Nägele \& Conrad 1990). No simple correlations have been found between $\mathrm{pH}$ changes and their effects on $\mathrm{N}_{2} \mathrm{O}$ production.

Combinations of environmental, population, and enzymatic effects make quantification of $\mathrm{N}_{2} \mathrm{O}$ production by specific bacterial groups very complicated in realworld systems. We have provided a brief overview of how interactions among all of these factors work together to produce a pool of $\mathrm{N}_{2} \mathrm{O}$ that is likely a combination of isotopic signatures with bias toward either nitrifying or denitrifying processes. Environments that are heavily influenced by a few parameters, such as recently fertilized or irrigated agricultural fields, often have a very strong bias from either nitrifying or denitrifying processes that can be discerned by relative quantities of specific $\mathrm{N}_{2} \mathrm{O}$ isotopomers and isotopologues (Pérez et al. 2001).

The current challenge for quantifying the global budget of $\mathrm{N}_{2} \mathrm{O}$ is to correlate the biological sources described above with sinks from chemical reactions in the atmosphere. The remaining portion of this review discusses the predominant sink of $\mathrm{N}_{2} \mathrm{O}$ in the atmosphere, i.e., preferential photolysis of $\mathrm{N}_{2} \mathrm{O}$ isotopomers. Additionally, we present how direct measurements of the isotopic composition of $\mathrm{N}_{2} \mathrm{O}$ from both the biosphere and the stratosphere are furthering the goal of closing the $\mathrm{N}_{2} \mathrm{O}$ budget.

\section{FATE OF $\mathrm{N}_{2} \mathrm{O}$ IN THE ATMOSPHERE AND ISOTOPIC FRACTIONATION}

Once $\mathrm{N}_{2} \mathrm{O}$ is produced and released into the environment, it is removed from the atmosphere by photodissociation, which accounts for $90 \%$ of the total $\mathrm{N}_{2} \mathrm{O}$ sink,

$$
\mathrm{N}_{2} \mathrm{O}+\mathrm{h} v \rightarrow \mathrm{N}_{2}+\mathrm{O}\left({ }^{1} \mathrm{D}\right) .
$$

The rest is lost via the photo-oxidation reaction with $\mathrm{O}\left({ }^{1} \mathrm{D}\right)$, an excited state of the $\mathrm{O}$ atom derived from photolysis of $\mathrm{O}_{3}$,

$$
\begin{aligned}
\mathrm{N}_{2} \mathrm{O}+\mathrm{O}\left({ }^{1} \mathrm{D}\right) & \rightarrow 2 \mathrm{NO} \\
& \rightarrow \mathrm{N}_{2}+\mathrm{O}_{2}
\end{aligned}
$$

Both Reactions 1 and 2 primarily take place in the stratosphere, resulting in a mean lifetime of over 100 years for $\mathrm{N}_{2} \mathrm{O}$. Reaction $2 \mathrm{a}$ is the major source of odd nitrogen $\left(\mathrm{NO}_{\mathrm{x}}\right)$ to the stratosphere and plays a fundamental role in regulating the ozone layer (e.g., Logan et al. 1978, Wennberg et al. 1994). Figure 7 shows the distribution of $\mathrm{N}_{2} \mathrm{O}$ in the atmosphere for four representative months computed by the Caltech/JPL two-dimensional (2-D) model of the terrestrial atmosphere (Yung $\&$ Miller 1997). The surface concentration was set to $300 \mathrm{ppb} . \mathrm{N}_{2} \mathrm{O}$ is well mixed 

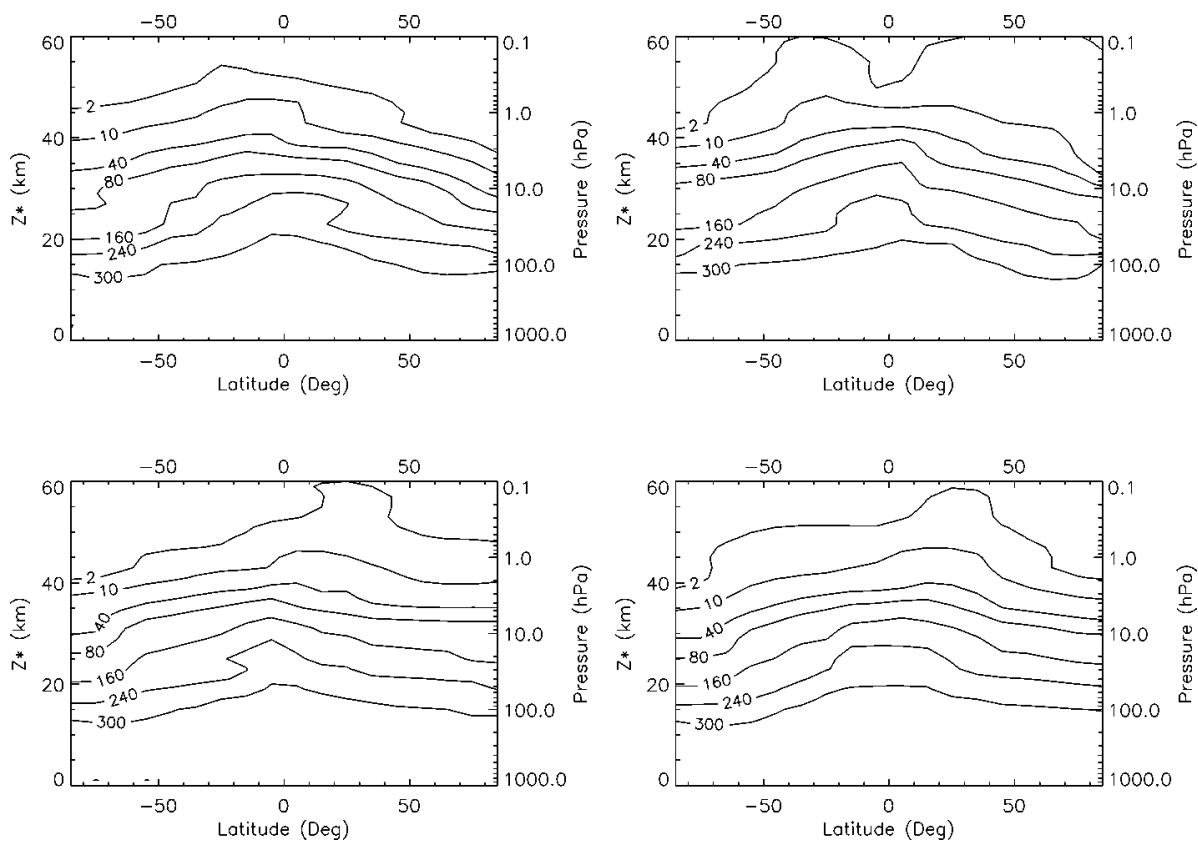

Figure 7 Mixing ratio of $\mathrm{N}_{2} \mathrm{O}$ in the atmosphere computed by the Caltech/JPL 2-D model of the terrestrial atmosphere: (a) January, (b) April, (c) July, and (d) October. The units are ppb. The surface mixing of $\mathrm{N}_{2} \mathrm{O}$ is $300 \mathrm{ppb}$ in the model. The pressure (P) in hPa refers to the left axis. The altitude $\left(Z^{*}\right)$ is defined by $Z^{*}=6.948712 \mathrm{~km} \times \log _{10}(1000 / \mathrm{P})$ and can be regarded as an approximate altitude.

in the troposphere because of its long lifetime. The decrease in mixing ratio in the stratosphere is the result of the aforementioned reactions, and is borne out by measurements (e.g., Gunson et al. 1990). The bulge in the contours in the tropics is due to the upwelling of tropospheric air that is rich in $\mathrm{N}_{2} \mathrm{O}$. The low mixing ratios in the polar stratosphere are due to the downwelling of upper stratospheric air that is depleted in $\mathrm{N}_{2} \mathrm{O}$. The exchange of air between the troposphere and the stratosphere is known as the Brewer-Dobson circulation (Holton et al. 1995). This circulation is strongest in the winter hemisphere, and its effects on $\mathrm{N}_{2} \mathrm{O}$ are evident in the north (south) polar stratosphere in January (July). The model results shown in Figure 7 are consistent with measurements obtained by the Upper Atmosphere Research Satellite (UARS) (Kumer et al. 1993). Version 9 of the UARS data for $\mathrm{N}_{2} \mathrm{O}$ is currently available at the Goddard DAAC for the period October 25, 1991 to May 5, 1993 from 20 to $50 \mathrm{~km}$. For details, refer to the website http://www.lmsal.com/9120/CLAES/.

Following the discovery of the $\mathrm{N}_{2} \mathrm{O}$ isotopic anomaly by Kim \& Craig (1993), Johnston et al. (1995) attempted to verify the suggestion that stratospheric 
chemistry results in $\mathrm{N}_{2} \mathrm{O}$ isotopic fractionation. Yung \& Miller (1997) proposed a wavelength-dependent mechanism for the photolytic fractionation of $\mathrm{N}_{2} \mathrm{O}$ based on subtle shifts in the zero point energy with isotopic substitution. For example, substituting ${ }^{18} \mathrm{O}$ for ${ }^{16} \mathrm{O}$ results in a calculated zero point energy blue shift for the heavier isotopologue of $-27.5 \mathrm{~cm}^{-1}$. Analogous to determining the kinetic fractionation for a chemical reaction, the photolytic fractionation factor will be equal to the ratio of the heavy-to-light photolysis rates and thus to the ratio of the cross sections. For $\mathrm{N}_{2} \mathrm{O}$, the theoretical enrichment factors can be calculated analytically as a function of wavelength using the spectral function of Selwyn et al. (1977) and the Yung \& Miller (1997) model was able to match, at least qualitatively, the observed enrichments of both ${ }^{15} \mathrm{~N}$ and ${ }^{18} \mathrm{O}$.

Photolysis experiments investigating the validity of the Yung \& Miller (1997) theory were performed by several different research teams (Rahn et al. 1998, Röckmann et al. 2000, Turatti et al. 2000, Zhang et al. 2000). The data are clearly consistent with a simple Rayleigh fractionation model, and the trend of the heavy isotope enrichment with wavelength was consistent with that predicted by Yung \& Miller (1997). It was observed that enrichments of ${ }^{15} \mathrm{~N}$ to ${ }^{18} \mathrm{O}$ yields ratios were slightly greater than unity at wavelengths close to the effective, or mean, stratospheric photolysis wavelength of $205 \mathrm{~nm}$. This is nearly identical to the ratio of the enrichments observed in Rahn \& Wahlen (1997) and close to that predicted in Figure 2 of Yung \& Miller (1997); it supports the hypothesis that photolysis is the principal mechanism responsible for the observed stratospheric enrichments and that the standard model of stratospheric $\mathrm{N}_{2} \mathrm{O}$ chemistry is essentially complete. Turatti et al. (2000) and Zhang et al. (2000) observed that the fractionation rate for the ${ }^{14} \mathrm{~N}^{15} \mathrm{~N}^{16} \mathrm{O}$ isotopomer was greater than the rate for the ${ }^{15} \mathrm{~N}^{14} \mathrm{~N}^{16} \mathrm{O}$, as predicted by the Yung \& Miller (1997) hypothesis. However, the magnitudes of the experimentally determined enrichments were all found to be much greater than that predicted by YM97 Yung \& Miller (1997). For example, the ${ }^{18} \mathrm{O}$ fractionation at $207.6 \mathrm{~nm}$ was found to be -46.0 per mil, more than twice that predicted by Yung \& Miller (1997).

Theoretical efforts to extend photodestruction-induced isotopic fractionation to include other aspects of photolysis have been done by Johnson et al. (2001) and Blake et al. (2002). Factors other than ZPE that affect isotopic fractionation include the contribution of vibrationally excited $\mathrm{N}_{2} \mathrm{O}$ in the ground electronic state, the transition dipole moment, and the shape of the ground-state wavefunction. Because the electronically excited state of $\mathrm{N}_{2} \mathrm{O}$ is bent, vibrational excitation of $\mathrm{N}_{2} \mathrm{O}$ in the ground electronic state leads to better Franck-Condon overlap and a larger contribution to the overall absorption profile. This would lead to a temperature dependence on isotopomer fractionation. Changes in the vibrational wavefunction causes the absorption profile to narrow, especially for $\mathrm{N}_{2} \mathrm{O}$ in the 200-215-nm region, the critical region for photolysis in the stratosphere. Johnson et al. (2001), using time-dependent Hermite propagation, can reproduce the laboratory results of enrichment for all of the isotopomers with the exception of the ${ }^{15} \mathrm{~N}^{14} \mathrm{~N}^{16} \mathrm{O}$ isotopomer. Blake et al. (2002) have taken a simpler, semi-empirical approach to 


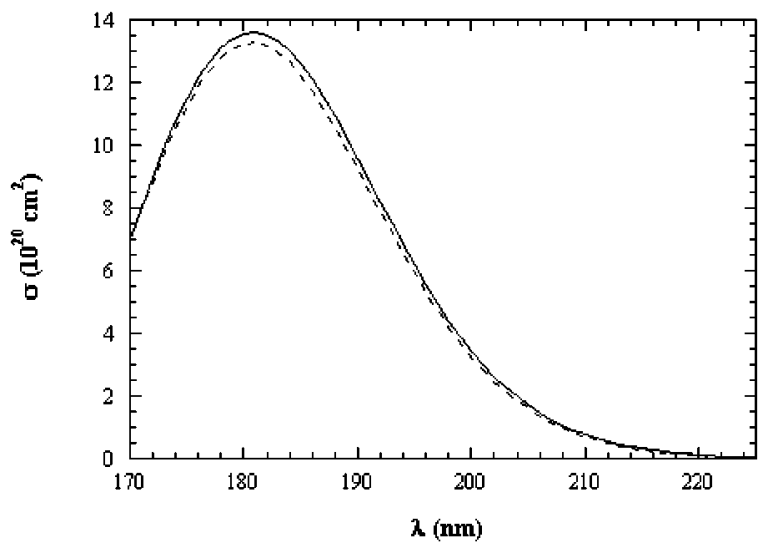

Figure 8 Absorption cross-sections of $\mathrm{N}_{2} \mathrm{O}$ isotopologues in the UV: ${ }^{14} \mathrm{~N}^{14} \mathrm{~N}^{16} \mathrm{O}$ (solid line) and ${ }^{14} \mathrm{~N}^{15} \mathrm{~N}^{16} \mathrm{O}$ (dashed line). The units are $10^{-20} \mathrm{~cm}^{2}$.

the theoretical calculation of enrichment factors, and the method has been able to reproduce stratospheric observations of $\mathrm{N}_{2} \mathrm{O}$ fractionation in the stratosphere. Figure 8 shows a comparison for the absorption cross-section for the most abundant isotopologue ${ }^{14} \mathrm{~N}^{14} \mathrm{~N}^{16} \mathrm{O}$ (solid line) and the minor isotopologue ${ }^{14} \mathrm{~N}^{15} \mathrm{~N}^{16} \mathrm{O}$ (dashed line). The heavier isotopomer has a slightly smaller cross-section, resulting in less destruction by photolysis and its enrichment relative to the main isotopologue.

Although Reaction 2 accounts for only $10 \%$ of the overall destruction of $\mathrm{N}_{2} \mathrm{O}$ in the atmosphere (Reaction 1 is the primary sink), in the lower stratosphere (below $22 \mathrm{~km}$ ) it is actually more important than photolysis. The fractionation in this reaction has recently been measured by Kaiser \& Brenninkmeijer (2002), and can be expressed as:

$$
\alpha=\mathrm{k}_{5} \text { (isotopologue) } / \mathrm{k}_{5} \text { (standard). }
$$

The laboratory measurements give $\alpha_{456}-1, \alpha_{546}-1$, and $\alpha_{448}-1$ as -8.87 , -2.22 , and -12.38 per mil, respectively, where pqr is a shorthand for an isotopologues of $\mathrm{N}_{2} \mathrm{O},{ }^{1 \mathrm{p}} \mathrm{N}^{1 \mathrm{q}} \mathrm{N}^{1 \mathrm{r}} \mathrm{O}$.

The isotopic fractionation due to Reactions 1-3 were incorporated in a recent study using the Caltech/JPL 2-D model (Morgan et al. 2002). The results for January are shown in Figure $9 a-d$ for $\delta^{18} \mathrm{O}, \delta^{17} \mathrm{O}, \delta^{15} \mathrm{~N}^{\alpha}$, and $\delta^{15} \mathrm{~N}^{\beta}$, respectively. There is little fractionation in the troposphere. The bulk of the isotopic fractionation takes place in the stratosphere and the $\delta$ values can reach as high as 100 per mil in the upper stratosphere. Model results above $40 \mathrm{~km}$ must be taken with caution, as the mixing ratio of $\mathrm{N}_{2} \mathrm{O}$ rapidly approaches zero (see Figure 7). Note that the destruction of $\mathrm{N}_{2} \mathrm{O}$ in the stratosphere results in the enrichment of the heavier 

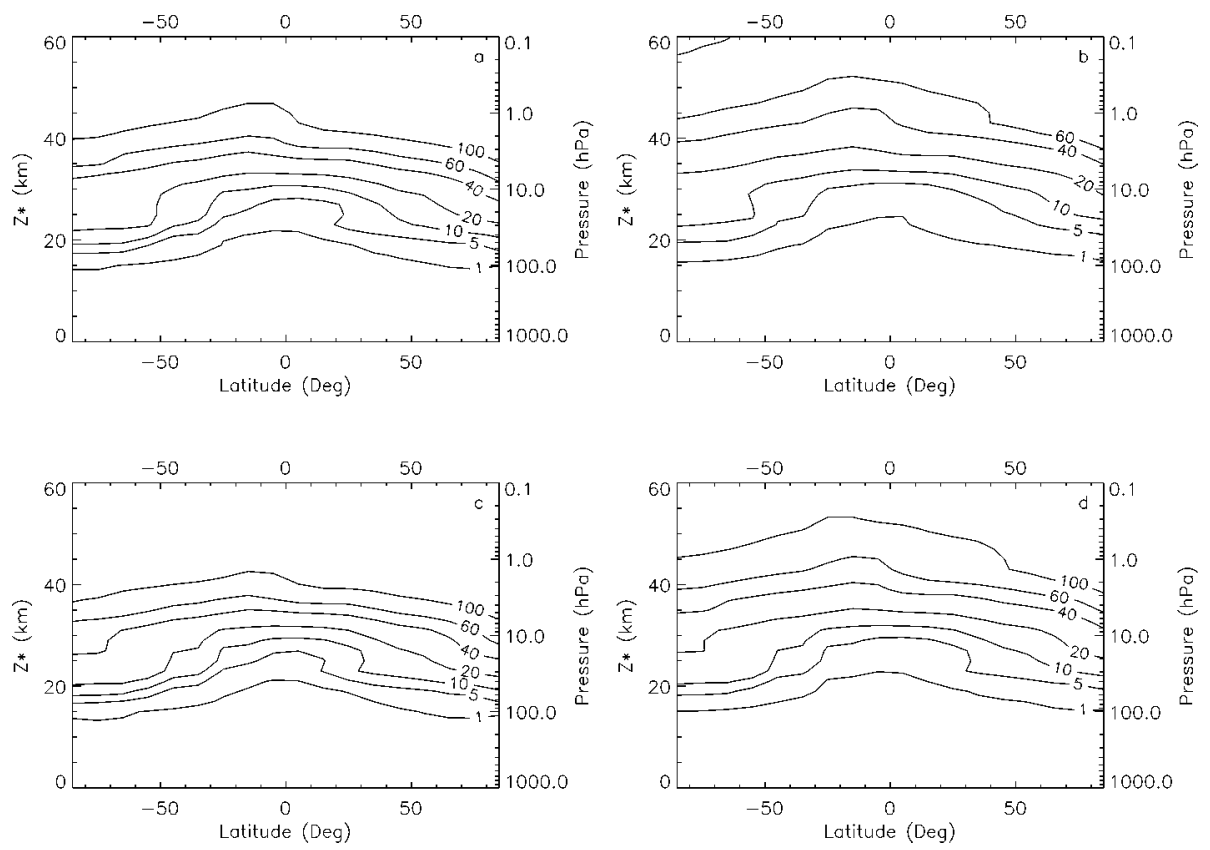

Figure 9 Isotopic fractionation of $\mathrm{N}_{2} \mathrm{O}$ due to Reactions 1 and 2 in the atmosphere as computed by the Caltech/JPL 2-D model: $(a) \delta^{18} \mathrm{O},(b) \delta^{17} \mathrm{O},(c) \delta^{15} \mathrm{~N}^{\alpha}$, and $(d) \delta^{15} \mathrm{~N}^{\beta}$.

isotopologues. Therefore, the stratosphere is a source of isotopically heavy $\mathrm{N}_{2} \mathrm{O}$, as first pointed out in the insightful analysis of Kim \& Craig (1993). The globally and seasonally averaged fractionation due to atmospheric chemistry for $\delta^{18} \mathrm{O}$, $\delta^{17} \mathrm{O}, \delta^{15} \mathrm{~N}^{\alpha}$, and $\delta^{15} \mathrm{~N}^{\beta}$ are 14.5, 6.4, 20.0, and 9.8, respectively. If we do not distinguish between $\delta^{15} \mathrm{~N}^{\alpha}$ and $\delta^{15} \mathrm{~N}^{\beta}$ (as in a mass spectrometer), we can define a mean $\delta^{15} \mathrm{~N}=\left(\delta^{15} \mathrm{~N}^{\alpha}+\delta^{15} \mathrm{~N}^{\beta}\right) / 2=14.9$. The quantitative determination of these fractionation values will now allow an estimation of the mean isotopic composition of the sources of $\mathrm{N}_{2} \mathrm{O}$.

\section{MEASURING $\mathrm{N}_{2} \mathrm{O}$ ISOTOPOLOGUESAND ISOTOPOMERSTO QUANTIFY INDIVIDUAL SOURCES AND SINKS OF $\mathrm{N}_{2} \mathrm{O}$}

Given the large uncertainties in estimates for sources of $\mathrm{N}_{2} \mathrm{O}$, as shown in Table 1, it is natural to ask whether the isotopic composition of the sources can pose useful constraints. As pointed out earlier, the combination of quantifying the isotopic composition of atmospheric $\mathrm{N}_{2} \mathrm{O}$ along with the modeling of isotopic fractionation due to reactions in the atmosphere allows us to estimate the isotopic composition of the source. The results are summarized in Figure 10, in which the mean atmospheric 


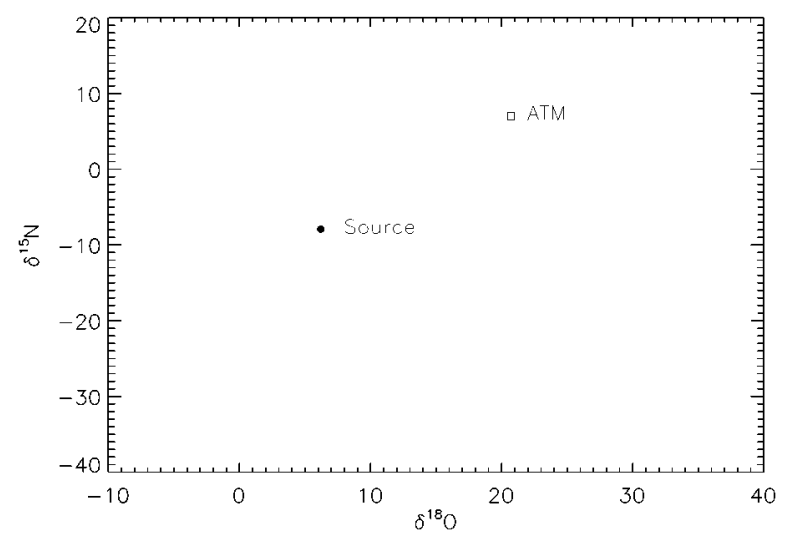

Figure 10 Isotopic composition of $\mathrm{N}_{2} \mathrm{O}$ : Square $=$ average of atmospheric composition, dot $=$ average of all sources.

isotopic composition is given by the square and the mean source is given by the dark dot. The source must be lighter than the atmosphere because of the enrichment of the heavy isotopes in the destruction processes in the stratosphere. Thus, the best estimate for the average isotopic composition of $\mathrm{N}_{2} \mathrm{O}$ is given by $\delta^{18} \mathrm{O}=7$ per mil and $\delta^{15} \mathrm{~N}=-7.5$ per mil. Referring to Figure 4, the above results imply that the ocean could not be a major source of $\mathrm{N}_{2} \mathrm{O}$. Additional information is available if we distinguish between $\delta^{15} \mathrm{~N}^{\alpha}$ and $\delta^{15} \mathrm{~N}^{\beta}$. Figure 11 summarizes recent measurements of $\delta^{15} \mathrm{~N}^{\alpha}$ and $\delta^{15} \mathrm{~N}^{\beta}$.

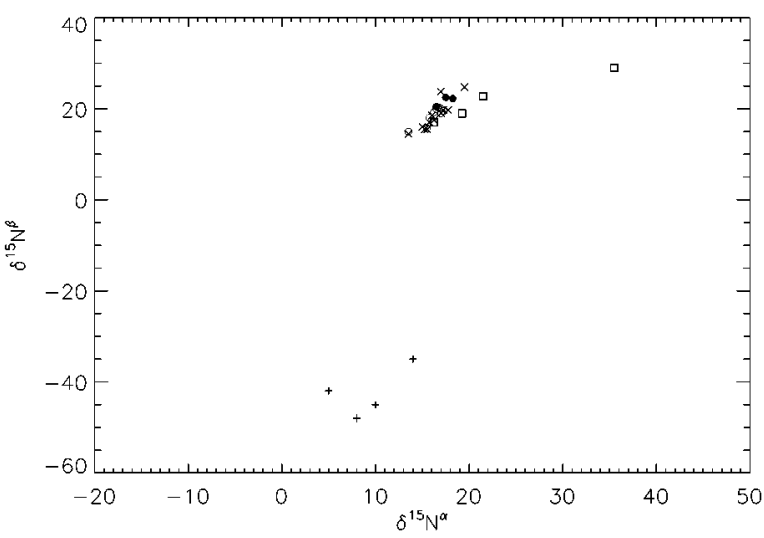

Figure 11 Isotopic composition of positional $\mathrm{N}_{2} \mathrm{O}$ in the troposphere, stratosphere, soil, and ocean. • from Yoshinari et al. 1997; o, $\times$ from Yoshida \& Toyoda 2000; and + from Pérez et al. 2001. 


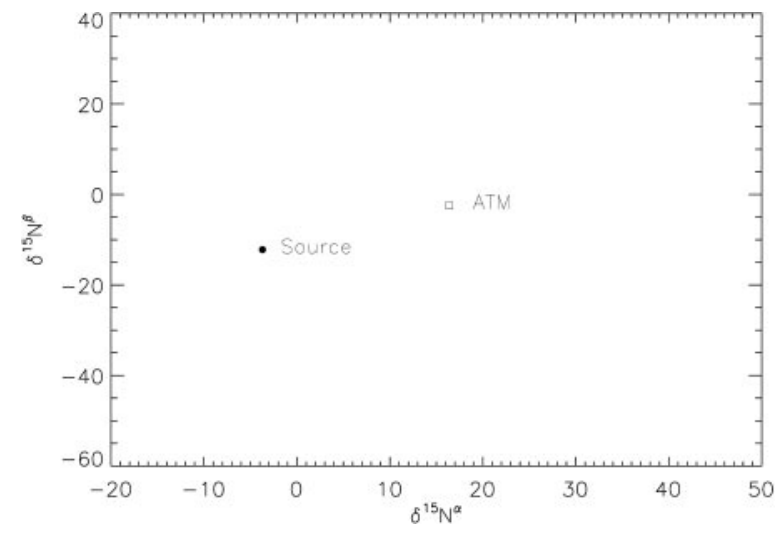

Figure 12 Isotopic composition of positional $\mathrm{N}_{2} \mathrm{O}$ : Square $=$ average of atmospheric composition, $\operatorname{dot}=$ average of all sources.

The average atmospheric and the implied source composition are shown in Figure 12. The characteristic values of $\delta^{15} \mathrm{~N}^{\alpha}$ and $\delta^{15} \mathrm{~N}^{\beta}$ should provide powerful further constraints on the sources. For example, the average source must have a small positive $\delta^{15} \mathrm{~N}^{\alpha}$ but a large negative $\delta^{15} \mathrm{~N}^{\beta}$. Isotopic measurements of $\mathrm{N}_{2} \mathrm{O}$ from fertilized agricultural soils are consistent with this constraint (Pérez et al. 2001). In a perceptive analysis, Rahn \& Wahlen (2000) pointed out that the isotopic budget evolved with time, implying that $\mathrm{N}_{2} \mathrm{O}$ is generated from a biological source. Their simple model predicted a decrease in $\delta^{18} \mathrm{O}$ and $\delta^{15} \mathrm{~N}$ of about 1.6 and 1.8 per mil, respectively, since the Industrial Revolution. Preliminary results from ice cores appear to support this simple model (T. Röckmann, unpublished data).

\section{CONCLUDING REMARKS}

Judging from the current datasets for global sources of $\mathrm{N}_{2} \mathrm{O}$ (Table 1), biological processes contribute by far the most $\mathrm{N}_{2} \mathrm{O}$ to the atmosphere relative to purely industrial sources. Additions of nitrogen to the environment, especially in agricultural and wet soils, greatly stimulate the microbial nitrogen cycle leading to large-scale production and emission of nitrogen oxide intermediates (based on gas production per unit area). This review has presented the current understanding of how microorganisms produce $\mathrm{N}_{2} \mathrm{O}$ and the various biological and environmental factors that control nitrogen cycling processes. We are now closer than ever to understanding how different microorganisms produce different ratios of $\mathrm{N}_{2} \mathrm{O}$ isotopologues and isotopomers. It is also evident that further study must be accomplished from enzymological to landscape ecology scales to fully appreciate and quantify discrete sources of $\mathrm{N}_{2} \mathrm{O}$. 
A most-powerful method for characterizing the sources of $\mathrm{N}_{2} \mathrm{O}$ lies in its multiisotope signature. It is now known that $(a)$ the major land biospheric sources of $\mathrm{N}_{2} \mathrm{O}$ are light in both ${ }^{15} \mathrm{~N}$ and ${ }^{18} \mathrm{O}$, relative to tropospheric $\mathrm{N}_{2} \mathrm{O} ;(b)$ stratospheric loss of $\mathrm{N}_{2} \mathrm{O}$ results in enriching both ${ }^{15} \mathrm{~N}$ and ${ }^{18} \mathrm{O}$; and $(c)$ there is a large "back flux" of heavy $\mathrm{N}_{2} \mathrm{O}$ from the stratosphere to the troposphere. Therefore, if we could compute $(c)$ accurately in an atmospheric model, we could have a constraint on the isotopic composition of the biological source. By assigning production of specific isotopomers and isotopologes of $\mathrm{N}_{2} \mathrm{O}$ to different microbial groups, and by quantifying the rates of photolysis of specific $\mathrm{N}_{2} \mathrm{O}$ pools, we are determining the conditions for $\mathrm{N}_{2} \mathrm{O}$ production in the biosphere and tracing its fate in the atmosphere.

The combination of knowledge from both biological and atmospheric sciences is rapidly leading to a tightened global budget for $\mathrm{N}_{2} \mathrm{O}$. The information from this collaboration will greatly improve international efforts to stem the continued accumulation $\mathrm{N}_{2} \mathrm{O}$ to the atmosphere by expanding and encompassing the scientific view from molecular to global levels.

\section{ACKNOWLEDGMENTS}

We thank J. Tung, K. Campbell, H.J. Chiang, and F.L. Jordan for helpful comments. This work was supported in part by an NSF grant and a grant from the Davidow Foundation.

\section{The Annual Review of Earth and Planetary Science is online at http://earth.annualreviews.org}

\section{LITERATURE CITED}

Anderson IC, Poth M, Homstead J, Burdige D. 1993. A comparison of $\mathrm{NO}$ and $\mathrm{N}_{2} \mathrm{O}$ production by the autotrophic nitrifier Nitrosomonas europaea and the heterotrophic nitrifier $\mathrm{Al}$ caligenes faecalis. Appl. Environ. Microbiol. 59:3525-33

Auman AJ, Speake CC, Lidstrom ME. 2001. nifH sequences and nitrogen fixation in Type I and Type II methanotrophs. Appl. Environ. Microbiol. 67:4009-16

Averill BA. 1996. Dissimilatory nitrite and nitric oxide reductases. Chem. Rev. 96:295164

Barford CC, Montoya JP, Altabet MA, Mitchell R. 1999. Steady-state nitrogen isotope effects of $\mathrm{N}_{2}$ and $\mathrm{N}_{2} \mathrm{O}$ production of Paracoccus denitrificans. Appl. Environ. Microbiol. 65:98994

Battle M, Bender M, Sowers T, Tans PP, Butler JH, et al. 1996. Atmospheric gas concen- trations over the past century measured in air from firn at South Pole. Nature 383:23135

Baumgärtner M, Conrad R. 1992. Role of nitrate and nitrite for production and consumption of nitric oxide during denitrification in soil. FEMS Microb. Ecol. 101: 59-65

Baumgärtner M, Koschorreck M, Conrad R. 1996. Oxidative consumption of nitric oxide by heterotrophic bacteria in soil. FEMS Microbiol. Ecol. 19:165-70

Beaumont HJE, Hommes NG, Sayavedra-Soto LA, Arp DJ, Arciero DM, et al. 2002. Nitrite reductase of Nitrosomonas europaea is not essential for production of gaseous nitrogen oxides and confers tolerance to nitrite. $J$. Bacteriol. 184:2557-60

Beaumont VI, Jahnke LL, Des Marais DJ. 2000. Nitrogen isotopic fractionation in the synthesis of photosynthetic pigments in 
Rhodobacter capsulatus and Anabaena cylindrica. Org. Geochem. 31:1075-85

Bell LC, Ferguson SJ. 1991. Nitric oxide and nitrous oxide reductases are active under aerobic conditions in cells of Thiosphaera pantotropha. Biochem. J. 273:423-27

Blake GA, Liang NC, Morgan CG, Yung YL. 2002. Photolytic fractionation of stratospheric nitrous oxide. EOS Trans. Am. Geophys. Union 83:48

Bock E. 1995. Nitrogen loss caused by denitrifying Nitrosomonas cells using ammonium or hydrogen as electron donors and nitrite as electron acceptor. Arch. Microbiol. 163:1620

Bock E, Koops H-P. 1991. The genus Nitrobacter and related genera. In The Prokaryotes, ed. K-H Schleifer, pp. 2302-9. New York: Springer-Verlag

Brittain T, Blackmore R, Greenwood C, Thomson AJ. 1992. Bacterial nitrite-reducing enzymes. Eur. J. Biochem. 209:793-802

Butler JH, Montzka SA, Clarke AD, Lobert JM, Elkins JW. 1998. Nitrous oxide and halocompounds. In Climate Monitoring and Diagnostics Laboratory Summary Report No. 24, 1996-1997, eds. DJ Hofmann, JT Peterson and RM Rosson, pp. 91-121. Boulder, CO: NOAA

Casciotti K, Rahn T, Wahlen M. 1997. Stable isotopes of $\mathrm{N}$ and $\mathrm{O}$ in nitrous oxide emissions from fertilized soils. EOS Trans. Am. Geophys. Union 78:F58 (Fall Meet. Suppl.)

Casciotti KL, Ward BB. 2001. Dissimilatory nitrite reductase genes from autotrophic ammonia-oxidizing bacteria. Appl. Environ. Microbiol. 67:2213-21

Castignetti D, Yanong R, Gramzinski R. 1984. Heterotrophic nitrification among denitrifiers. Appl. Environ. Microbiol. 47:620-23

Cleland WW, O'Leary MH, Northrop DB, eds. 1977. Isotope Effects on Enzyme-Catalyzed Reactions: Proceedings of the Sixth Annual Harry Steenbock Symposium. Baltimore, MD: Univ. Park Press

Colliver BB, Stephenson T. 2000. Production of nitrogen oxide and dinitrogen oxide by autotrophic nitrifiers. Biotech. Adv. 18:219-32
Conrad R. 1996. Soil microorganisms as controllers of atmospheric trace gases $\left(\mathrm{H}_{2}, \mathrm{CO}\right.$, $\mathrm{CH}_{4}, \mathrm{OCS}, \mathrm{N}_{2} \mathrm{O}$, and NO). Microbiol. Rev. 60:609-40

Coyne MS, Arunakumari A, Averill BA, Tiedje JM. 1989. Immunological identification and distribution of dissimilatory heme $\mathrm{cd}_{1}$ and nonheme copper nitrite reductases in denitrifying bacteria. Appl. Environ. Microbiol. 55:2924-31

Coyne MS, Arunakumari A, Pankratz HS, Tiedje JM. 1990. Localization of the cytochrome $\mathrm{cd}_{1}$ and copper nitrite reductases in denitrifying bacteria. J. Bacteriol. 172:255862

Craig H. 1961. Standard for reporting concentrations for deuterium and oxygen-18 in natural waters. Science 133:1833-34

Crutzen PJ. 1983. Atmospheric interactions. Homogeneous gas reactions of $\mathrm{C}, \mathrm{N}$, and $\mathrm{S}$ containing compounds. In The Major Biogeochemical Cycles and their Interactions, SCOPE 21, ed. RB Cook, pp. 67-114. New York: Wiley

Cutruzzolà F. 1999. Bacterial nitric oxide synthesis. Biochim. Biophys. Acta 1411:231-49

Dalton H. 1977. Ammonia oxidation by the methane oxidising bacterium Methylococcus capsulatus strain Bath. Arch. Microbiol. 114:273-79

Davidson EA. 1993. Soil water content and the ratio of nitrous oxide and nitric oxide emitted from soil. In Biogeochemistry of Global Change Radiatively Active Trace Gases: Selected Papers from the Tenth International Symposium on Environmental Biogeochemistry, San Francisco, August 19-24, 1991, ed. RS Oremland, pp. 369-86. New York: Chapman Hall

Dore JE, Popp BN, Karl DM, Sansone FJ. 1998. A large source of atmospheric nitrous oxide from subtropical North Pacific surface waters. Nature 396:63-66

Flückiger J, Dällenbach A, Blunier T, Stauffer B, Stocker TF, et al. 1999. Variations in atmospheric $\mathrm{N}_{2} \mathrm{O}$ concentration during abrupt climatic changes. Science 285:227-30

Freitag A, Bock E. 1990. Energy conservation 
in Nitrobacter. FEMS Microbiol. Lett. 66: 157-62

Freitag A, Rudert M, Bock E. 1987. Growth of Nitrobacter by dissimilatoric nitrate reduction. FEMS Microbiol. Lett. 48:105-9

Garber EAE, Hollocher TC. $1982 \mathrm{a} .{ }^{15} \mathrm{~N},{ }^{18} \mathrm{O}$ tracer studies on the activation of nitrite by denitrifying bacteria. J. Biol. Chem. 257: 8091-97

Garber EAE, Hollocher TC. 1982b. Positional isotopic equivalence of nitrogen in $\mathrm{N}_{2} \mathrm{O}$ produced by the denitrifying bacterium Pseudomonas stutzeri. J. Biol. Chem. 257:4705-8

Gaskell JF, Blackmer AM, Bremner JM. 1981. Comparison of effects of nitrate, nitrite, and nitric oxide on reduction of nitrous oxide to dinitrogen by soil microorganisms. Soil Sci. Soc. Am. J. 45:1124-27

Goody RM, Yung YL. 1989. Atmospheric Radiation: Theoretical Basis. New York: Oxford Univ. Press

Goreau TJ, Kaplan WA, Wofsy SC, McElroy MB, Valois FW, Watson SW. 1980. Production of $\mathrm{NO}_{2}^{-}$and $\mathrm{N}_{2} \mathrm{O}$ by nitrifying bacteria at reduced concentrations of oxygen. Appl. Environ. Microbiol. 40:526-32

Gunson MR, Farmer CB, Norton RH, Zander $\mathrm{R}$, Rinsland CP, et al. 1990. Measurements of $\mathrm{CH}_{4}, \mathrm{~N}_{2} \mathrm{O}, \mathrm{CO}, \mathrm{H}_{2} \mathrm{O}$, and $\mathrm{O}_{3}$ in the middle atmosphere by the atmospheric trace molecule spectroscopy experiment on SPACELAB-3. J. Geophys. Res.-Atmos. 95(D9):13867-82

Hendriks J, Oubrie A, Castresana J, Urbani A, Gemeinhardt S, Saraste M. 2000. Nitric oxide reductases in bacteria. Biochim. Biophys. Acta 1459:266-73

Hochstein LI, Tomlinson GA. 1988. The enzymes associated with denitrification. Annu. Rev. Microbiol. 42:231-61

Hoering TC, Ford HT. 1960. The isotope effect in the fixation of nitrogen by Azotobacter. $J$. Am. Chem. Soc. 82:376-78

Holmes AJ, Costello A, Lidstrom ME, Murrell JC. 1995. Evidence that particulate methane monooxygenase and ammonia monooxygenase may be related. FEMS Microbiol. Lett. 132:203-8

Holton JR, Haynes PH, McIntyre ME, Douglass
AR, Rood RB, Pfister L. 1995. Stratospheretroposphere exchange. Rev. Geophys. 33: 403-39

Hooper AB. 1968. A nitrite-reducing enzyme from Nitrosomonas europaea. Preliminary characterization with hydroxylamine as electron donor. Biochim. Biophys. Acta 162:4965

Hooper AB, Terry KR. 1979. Hydroxylamine oxidoreductase of Nitrosomonas, production of nitric oxide from hydroxylamine. Biochim. Biophys. Acta. 571:12-20

Howarth RW, Billen G, Swaney D, Townsend A, Jaworski N, et al. 1996. Regional nitrogen budgets and riverine N\&P fluxes for the drainages to the North Atlantic Ocean: natural and human influences. Biogeochemistry 35:75-139

IPCC. 2001. Climate Change 2001: The Scientific Basis. Cambridge, UK: Cambridge Univ. Press

IUPAC. 1997. Compendium of Chemical Terminology, 2nd Edition. Boston: Blackwell Sci.

Jetten MSM, Wagner M, Fuerst J, van Loosdrecht M, Kuenen G, Strous M. 2001. Microbiology and application of the anaerobic ammonium oxidation ('anammox') process. Curr. Opin. Biotech. 12:283-88

Johnson MS, Billing GD, Gruodis A, Janssen MHM. 2001. Photolysis of nitrous oxide isotopomers studied by time-dependent hermite propagation. J. Phys. Chem. A 105:8672-80

Johnston JC, Cliff SS, Thiemens MH. 1995. Measurement of multioxygen isotopic $\left(\delta-\mathrm{O}^{18}\right.$ and $\delta-\mathrm{O}^{17}$ ) fractionation factors in the stratospheric sink reactions of nitrous oxide. $J$. Geophys. Res.-Atmos. 100(D8):16801-4

Killham K. 1986. Heterotrophic nitrification. In Nitrification, ed. JI Prosser, pp. 117-26. Oxford: IRL

Kim K-R, Craig H. 1990. Two-isotope characterization of $\mathrm{N}_{2} \mathrm{O}$ in the Pacific Ocean and constraints on its origin in deep water. Nature 347:58-61

Kim K-R, Craig H. 1993. Nitrogen-15 and oxygen-18 characteristics of nitrous oxide: a global perspective. Science 262:1855-57

Kizawa H, Tomura D, Oda M, Fukamizu A, 
Hoshino T, et al. 1991. Nucleotide sequence of the unique nitrate nitrite-inducible cytochrome P-450 cDNA from Fusarium oxysporum. J. Biol. Chem. 266:10632-37

Knowles R, Topp E. 1988. Some factors affecting nitrification and the production of nitrous oxide by the methanotrophic bacterium Methylosinus trichosporium OB3b. In Current Perpectives in Environmental Biogeochemistry, ed. P Nannipieri, pp. 383-93. Rome: Consiglione delle Richerche-I.P.R.A.

Kobayashi M, Shoun H. 1995. The coppercontaining dissimilatory nitrite reductase involved in the denitrifying system of the fungus Fusarium oxysporum. J. Biol. Chem. 270:4146-51

Kowalchuk GA, Stephen JR, DeBoer W, Prosser JI, Embley TM, Woldendorp JW. 1997. Analysis of ammonia-oxidizing bacteria of the $\beta$ subdivision of the class Proteobacteria in coastal sand dunes by denaturing gradient gel electrophoresis and sequencing of PCR-amplified 16S ribosomal DNA fragments. Appl. Environ. Microbiol. 63:148997

Krämer M, Baumgärtner M, Bender M, Conrad R. 1990. Consumption of NO by methanotrophic bacteria in pure culture and in soil. FEMS Microbiol. Ecol. 73:345-50

Kroeze C. 1999. Closing the global $\mathrm{N}_{2} \mathrm{O}$ budget: a retrospective analysis 1500-1994. Global Biogeochem. Cycles 13:1-8

Kuenen JG, Robertson LA. 1994. Combined nitrification-denitrification processes. FEMS Microbiol. Rev. 15:109-17

Kumer JB, Mergenthaler JL, Roche AE. 1993. CLAES $\mathrm{CH}_{4}, \mathrm{~N}_{2} \mathrm{O}$, and $\mathrm{CCl}_{2} \mathrm{~F}_{2}$ global data. Geophys. Res. Lett. 20:1239-42

Langenfields RL, Fraser PJ, Francey RJ, Steele LP, Porter LW, Allison CE. 1996. The cape grim air archive: the first seventeen years. In Baseline Atmospheric Program Australia, 1994-95, eds. RJ Francey, AL Dick and N Derek, pp. 53-70. Melbourne: Bur. Meteorol./CSIRO Div. Atmos. Res.

Lin JT, Stewart V. 1998. Nitrate assimilation by bacteria. Adv. Microb. Physiol. 39:1-30

Lipschultz F, Zafiriou OC, Wofsy SC, McElroy
MB, Valois FW, Watson SW. 1981. Production of $\mathrm{NO}$ and $\mathrm{N}_{2} \mathrm{O}$ by soil nitrifying bacteria. Nature 294:641-43

Logan JA, Prather MJ, Wofsy SC, McElroy MB. 1978. Global budgets for carbon-monoxide and nitrogen-oxides. EOS Trans. Am. Geophys. Union 59:1076

Machida T, Nakazawa T, Fujii Y, Aoki S, Watanabe O. 1995. Increase in the atmospheric nitrous oxide concentration during the last 250 years. Geophys. Res. Lett. 22: 2921-24

Mandernack KW, Kinney CA, Coleman D, Huang Y-S, Freeman KH, Bogner J. 2000. The biogeochemical controls of $\mathrm{N}_{2} \mathrm{O}$ production and emission in landfill cover soils: the role of methanotrophs in the nitrogen cycle. Environ. Microbiol. 2:298-309

Minschwaner KR, Carver RW, Briegleb BP, Roche AE. 1998. Infrared radiative forcing and atmospheric lifetimes of trace species based on observations from UARS. J. Geophys. Res. 103:23243-53

Moir JWB, Crossman LC, Sprio S, Richardson DJ. 1996. The purification of ammonia monooxygenase from Paracoccus denitrificans. FEBS Lett. 387:71-74

Morgan CG, Yung YL, Allen MA, Blake GA, Liang NC. 2002. Isotopic fractionation of atmospheric nitrous oxide. EOS Trans. Am. Geophys. Union 83:47

Mosier AR, Kroeze C. 1998. A new approach to estimate emissions of nitrous oxide from agriculture and its implications to the global $\mathrm{N}_{2} \mathrm{O}$ budget. Glob. Change Newsl. 34:8-14

Mosier AR, Kroeze C, Nevison CD, Oenema O, Seitzinger S, van Cleemput O. 1998. Closing the global $\mathrm{N} 2 \mathrm{O}$ budget: nitrous oxide emissions through the agricultural nitrogen cycleOECD/IPCC/IEA phase II development of IPCC guidelines for national greenhouse gas inventory methodology. Nutr. Cycl. Agroecosyst. 52:225-48

Nägele W, Conrad R. 1990. Influence of $\mathrm{pH}$ on the release of $\mathrm{NO}$ and $\mathrm{N}_{2} \mathrm{O}$ from fertilized and unfertilized soil. Biol. Fertil. Soils 10: 139-44

Nakano MM, Hoffmann T, Zhu Y, Jahn D. 1998. 
Nitrogen and oxygen regulation of Bacillus subtilis nasDEF encoding NADH-dependent nitrite reductase by TnrA and ResDE. J. Bacteriol. 180:5344-50

Naqvi SWA, Yoshinari T, Jayakumar DA, Altabet MA, Narvekar PV, et al. 1998. Budgetary and biogeochemical implications of $\mathrm{N}_{2} \mathrm{O}$ isotope signatures in the Arabian Sea. Nature 394:462-64

Nevison C, Holland E. 1997. A reexamination of the impact of anthropogenically fixed nitrogen on atmospheric $\mathrm{N}_{2} \mathrm{O}$ and the stratospheric $\mathrm{O}_{3}$ layer. Geophys. Res. Lett. 102: 25519-36

Olivier JGJ, Bouwman AF, van der Hoek KW, Berdowski JJM. 1998. Global air emission inventories for anthropogenic sources of $\mathrm{NOx}, \mathrm{NH}_{3}$, and $\mathrm{N}_{2} \mathrm{O}$ in 1990. Environ. Poll. 102:135-48

Olsen S, McLinden C, Prather M. 2001. Stratospheric N2O-NOy system: testing uncertainties in a three-dimensional framework. J. Geophys. Res.-Atmos. 106(D22):2877184

Pérez T, Trumbore SE, Tyler SC, Davidson EA, Keller M, de Camargo PB. 2000. Isotopic variability of $\mathrm{N}_{2} \mathrm{O}$ emisions from tropical forest soils. Glob. Biogeochem. Cycl. 14:525-35

Pérez T, Trumbore SE, Tyler SC, Matson PA, Ortiz-Monasterio I, et al. 2001. Identifying the agricultural imprint on the global $\mathrm{N}_{2} \mathrm{O}$ budget using stable isotopes. J. Geophys. Res. 106:9869-78

Postgate JR. 1998. Nitrogen Fixation. New York: Cambridge Univ. Press

Powlson DS, Saffigna PG, Kragt-Cottaar M. 1988. Denitrification at sub-optimal temperatures in soils from different climatic zones. Soil Biol. Biochem. 20:719-23

Prosser JI, ed. 1986. Nitrification, Vols. 20. Washington, DC: IRL. 219 pp.

Prosser JI. 1989. Autotrophic nitrification in bacteria. Adv. Microb. Physiol. 30:125-77

Radmer RJ, Kok B. 1979. Rate-temperature curves as an unambiguous indicator of biological activity in soil. Appl. Environ. Microbiol. 38:224-28

Rahn T, Wahlen M. 1997. Stable isotope enrich- ment in stratospheric nitrous oxide. Science 278:1776-78

Rahn T, Wahlen M. 2000. A reassessment of the global isotopic budget of atmospheric nitrous oxide. Glob. Biogeochem. Cycl. 14:537-43

Rahn T, Zhang H, Wahlen M, Blake GA. 1998. Stable isotope fractionation during ultraviolet photolysis of $\mathrm{N}_{2} \mathrm{O}$. Geophys. Res. Lett. 25:4489-92

Rasmussen T, Berks BC, Sanders-Loehr J, Dooley DM, Zumft WG, Thomson AJ. 2000. The catalytic center in nitrous oxide reductase, $\mathrm{Cu}-\mathrm{z}$, is a copper-sulfide cluster. Biochem. 39:12753-56

Remde A, Conrad R. 1990. Production of nitric oxide in Nitrosomonas europaea by reduction of nitrite. Arch. Microbiol. 154:187-91

Reuss JO, Smith RL. 1965. Chemical reaction of nitrites in acid soils. Soil Sci. Soc. Am. Proc. 29:267-70

Richardson DJ, Watmough NJ. 1999. Inorganic nitrogen metabolism in bacteria. Curr. Opin. Chem. Biol. 3:207-19

Röckmann TC, Brenninkmeijer AM, Wollenhaupt M, Crowley JN, Crutzen PJ. 2000. Measurement of the isotopic fractionation of ${ }^{15} \mathrm{~N}^{14} \mathrm{~N}^{16} \mathrm{O},{ }^{14} \mathrm{~N}^{15} \mathrm{~N}^{16} \mathrm{O}$, and ${ }^{14} \mathrm{~N}^{14} \mathrm{~N}^{18} \mathrm{O}$ in the UV photolysis of nitrous oxide. Geophys. Res. Lett. 27:1399-402

Saad OALO, Conrad R. 1993. Temperature dependence of nitrification, denitrification, and turnover of nitric oxide in different soils. Biol. Fertil. Soils 15:21-27

Selwyn G, Podolske JR, Johnston HS. 1977. Nitrous oxide ultraviolet absorption spectrum at stratospheric temperatures. Geophys. Res. Lett. 4:427-30

Shiro Y, Fujii M, Iizuka T, Adachi S, Tsukamoto K, et al. 1995. Spectroscopic and kinetic studies on reaction of cytochrome P450nor with nitric oxide. J. Biol. Chem. 270:1617-23

Steele LP, Langenfields RL, Lucarelli MP, Fraser PJ, Cooper LN, et al. 1996. Atmospheric methane, carbon dioxide, carbon monoxide, hydrogen, and nitrous oxide from Cape Grim air samples analysed by gas chromatography. In Baseline Atmospheric Program Australia, 1994-95, ed. N Derek, pp. 107-10. 
Melbourne: Bur. Meteorol./CSIRO Div. Atmos. Res.

Stein LY, Arp DJ. 1998. Loss of ammonia monooxygenase activity in Nitrosomonas europaea upon exposure to nitrite. Appl. Environ. Microbiol. 64:4098-102

Straub KL, Benz M, Schink B, Widdel F. 1996. Anaerobic, nitrate-dependent microbial oxidation of ferrous iron. Appl. Environ. Microbiol. 62:1458-60

Thamdrup B, Dalsgaard T. 2002. Production of $\mathrm{N}_{2}$ through anaerobic ammonium oxidation coupled to nitrite reduction in marine sediments. Appl. Environ. Microbiol. 68:131218

Turatti F, Griffith DWT, Wilson SR, Esler MB, Rahn T, et al. 2000. Positionally dependent $15 \mathrm{~N}$ factors in the UV photolysis of $\mathrm{N}_{2} \mathrm{O}$ determined by high resolution FTIR spectroscopy. Geophys. Res. Lett. 27:2489-92

Verstraete W. 1975. Heterotrophic nitrification in soils and aqueous media. Izvest. Akad. Nauk SSSR Ser. Biol. 4:541-58

Webster EA, Hopkins DW. 1996. Nitrogen and oxygen isotope ratios of nitrous oxide emitted from soil and produced by nitrifying and denitrifying bacteria. Biol. Fertil. Soils 22:326-30

Weeg-Aerssens E, Tiedje JM, Averill BA. 1988. Evidence from isotope labeling studies for a sequential mechanism for dissimilatory nitrite reduction. J. Am. Chem. Soc. 110:685156

Wehrfritz J-M, Reilly A, Spiro S, Richardson DJ. 1993. Purification of hydroxylamine oxidase from Thiosphaera pantotropha: Identification of electron acceptors that couple heterotrophic nitrification to aerobic denitrification. FEBS Lett. 335:246-50

Wennberg PO, Cohen RC, Stimpfle RM, Koplow JP, Anderson JG, et al. 1994. Removal of stratospheric $\mathrm{O}_{3}$ by radicals-in situ measurements of $\mathrm{OH}, \mathrm{HO}_{2}, \mathrm{NO}, \mathrm{NO}_{2}, \mathrm{ClO}$, and BrO. Science 266:398-404

Whittaker M, Bergmann D, Arciero D, Hooper AB. 2000. Electron transfer during the oxidation of ammonia by the chemolithotrophic bacterium Nitrosomonas europaea. Biochim. Biophys. Acta 1459:346-55

Wood PM. 1986. Nitrification as a bacterial energy source. In Nitrification, ed. JI Prosser, pp. 39-62. Oxford, UK: Soc. Gen. Microbiol, IRL

Ye RW, Thomas SM. 2001. Microbial nitrogen cycles: physiology, genomics and applications. Curr. Opin. Microbiol. 4:307-12

Yoshida N. 1988. ${ }^{15} \mathrm{~N}$-depleted $\mathrm{N}_{2} \mathrm{O}$ as a product of nitrification. Nature 335:528-29

Yoshida N, Toyoda S. 2000. Constraining the atmospheric $\mathrm{N} 2 \mathrm{O}$ budget from intramolecular site preference in $\mathrm{N} 2 \mathrm{O}$ isotopomers. Nature 405:330-34

Yoshinari T. 1984. Nitrite and nitrous oxide production by Methylosinus trichosporium. Can. J. Microbiol. 31:139-44

Yoshinari T, Altabet MA, Naqvi SWA, Codispoti L, Jayakumar A, et al. 1997. Nitrogen and oxygen isotopic compositions of $\mathrm{N}_{2} \mathrm{O}$ from suboxic waters of the eastern tropical North Pacific and the Arabian SeaMeasurement by continuous-flow isotoperatio monitoring. Mar. Chem. 56:253-64

Yung YL, Miller CE. 1997. Isotopic fractionation of stratospheric nitrous oxide. Science 278:1778-80

Zahn JA, Duncan C, DiSpirito AA. 1994. Oxidation of hydroxylamine by cytochrome P460 of the obligate methylotroph Methylococcus capsulatus Bath. J. Bacteriol. 176: 5879-87

Zhang $\mathrm{H}$, Wennberg PO, Wu VH, Blake GA. 2000. Fractionation of ${ }^{14} \mathrm{~N}^{15} \mathrm{~N}^{16} \mathrm{O}$ and ${ }^{15} \mathrm{~N}^{14} \mathrm{~N}^{16} \mathrm{O}$ during photolysis at $213 \mathrm{~nm}$. Geophys. Res. Lett. 27:2481-84

Zhao XJ, Sampath V, Caughey WS. 1995. Cytochrome-c-oxidase catalysis of the reduction of nitric-oxide to nitrous-oxide. Biochem. Biophys. Res. Comm. 212:1054-60

Zumft WG. 1992. The denitrifying prokaryotes. In The Prokaryotes, ed. M Dworkin, pp. 55482. New York: Springer Verlag

Zumft WG. 1993. The biological role of nitric oxide in bacteria. Arch. Microbiol. 160:25364 
蛋 Annual Review of Earth and Planetary Sciences

Volume 31, 2003

\section{CONTENTS}

Frontispiece-G.J. Wasserburg xvi

ISOTOPIC AdVENTURES-GEOLOGICAL, PlANETOLOGICAL, AND COSMIC, G.J. Wasserburg 1

TROPICAL CyClONES, Kerry Emanuel $\quad 75$

Phanerozoic Atmospheric OXYgen, Robert A. Berner,

David J. Beerling, Robert Dudley, Jennifer M. Robinson, and

Richard A. Wildman, Jr. 105

METAL-SiliCATE PARTITIONING OF SidEROPHILE ElEMENTS AND CORE FORMATION IN THE EARLY EARTH, Kevin Righter 135

Volcanic Activity on Io DURING the Galileo ERA, Paul E. Geissler 175

MADAGASCAR: HEADS IT'S A CONTINENT, TAILS IT'S AN ISLAND, Maarten J. de Wit

THE EFFECTS OF BIOTURBATION ON SOIL PROCESSES AND

SEDIMENT TRANSPORT, Emmanuel J. Gabet, O.J. Reichman, and Eric W. Seabloom

THE Role of DECAY AND Mineralization IN THE PRESERVATION OF SOFT-BODIED FOSSILS, Derek E.G. Briggs

Global Mantle TOMOgRaPhy: PROGRESS Status IN THE

PAST 10 YEARS, Barbara Romanowicz

PRODUCTION, ISOTOPIC COMPOSITION, AND ATMOSPHERIC FATE OF

BiologiCAlly PRODUCED NitRous OXIDE, Lisa Y. Stein and

Yuk L. Yung

PHYLOGENETIC APPROACHES TOWARD CROCODYLIAN HistoRy, Christopher A. Brochu

RHEOLOGY OF GRANITIC MAGMAS DURING ASCENT AND

EMPLACEMENT, Nick Petford

THE INDIAN MONSOON AND ITS VARIABILITY, Sulochana Gadgil

ReCognizing MANTLE Plumes In THE GeOlOGicAl ReCORD,

Richard E. Ernst and Kenneth L. Buchan

Catastrophic Flooding of THE Black SeA, William B.F. Ryan,

Candace O. Major, Gilles Lericolais, and Steven L. Goldstein 
HOLOCENE EARTHQUAKE RECORDS FROM THE CASCADIA SUbDUCTION ZONE AND NORTHERN SAN ANDREAS FAUlT BASED ON PRECISE DATING OF OFFShORE TURBIDITES, Chris Goldfinger,

C. Hans Nelson, Joel E. Johnson, and The Shipboard Scientific Party

IS El Niño SPORADIC OR CYCLIC?, S. George Philander and Alexey Fedorov

\section{INDEXES}

Subject Index

Cumulative Index of Contributing Authors, Volumes 21-31 625

Cumulative Index of Chapter Titles, Volumes 21-31

ERRATA

An online log of corrections to Annual Review of Earth and

Planetary Sciences chapters (if any, 1997 to the present)

may be found at http://earth.annualreviews.org 